\title{
River inflow and salinity changes in the Caspian Sea during the last 5500 years
}

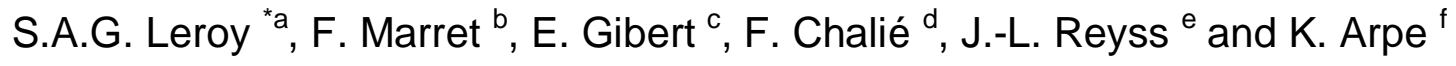 \\ a Institute for the Environment, Brunel University, Uxbridge UB8 3PH, West \\ London, UK, suzanne.leroy@brunel.ac.uk \\ ${ }^{\mathrm{b}}$ Department of Geography, University of Liverpool, Liverpool L69 7ZT, UK, \\ f.marret@liverpool.ac.uk \\ ${ }^{c}$ UMR8148-IDES, CNRS-UPS, Université Paris-Sud, Bâtiment 504, F-91405 \\ Orsay cedex, France, egibert@geol.u-psud.fr \\ d CEREGE, UMR-6635 CNRS-UPCAM, Europôle de l'Arbois, BP80, F-13545 \\ Aix-en-Provence cedex 04, France, chalie@cerege.fr \\ e Laboratoire des Sciences du Climat et de l'Environnement, CEA-CNRS, \\ avenue de la Terrasse, F-91198 Gif-sur-Yvette Cedex, France, Jean- \\ Louis.Reyss@Isce.cnrs-gif.fr \\ ${ }^{f}$ Max Planck Institute for Meteorology, Hamburg, Germany. \\ klaus.arpe@zmaw.de
}

${ }^{*}$ Corresponding author: tel. +44-1895-266087, fax: +44-1895-269736

\begin{abstract}
Pollen, spores and dinoflagellate cysts have been analysed on three sediment cores (1.8 to $1.4 \mathrm{~m}$-long) taken from the south and middle basins of the Caspian Sea. A chronology available for one of the cores is based on calibrated radiocarbon dates (ca 5.5-0.8 cal. ka BP). The pollen and spores assemblages indicate fluctuations between steppe and desert. In addition there are some outstanding zones with a bias introduced by strong river inflow. The dinocyst assemblages change between slightly brackish (abundance of Pyxidinopsis psilata and Spiniferites cruciformis) and more brackish (dominance of Impagidinium caspienense) conditions. During the second part of the Holocene, important flow modifications of the Uzboy River and the Volga River as well as salinity changes of the Caspian Sea, causing sea-level fluctuations, have been reconstructed. A major change is suggested at ca 4 cal. ka BP with the end of a high level phase in the south basin. Amongst other hypotheses, this could be caused by the end of a late and abundant flow of the Uzboy River (now defunct), carrying to the Caspian Sea either meltwater from higher latitudes or water from the Amu-Daria. A similar, later clear phase of water inflow has also been observed from 2.1 to $1.7 \mathrm{cal}$. $\mathrm{ka} \mathrm{BP}$ in the south basin and probably also in the north of the middle basin.
\end{abstract}

\section{Key words}

Caspian Sea, pollen, dinocysts, salinity, river flow, Holocene 


\section{Introduction}

The Caspian Sea (CS) levels have changed dramatically over various timescales both erratically and cyclically (Kazancı et al., 2004), causing vast modifications in both the volume and the area of the water body. During the $20^{\text {th }} \mathrm{C}$., CS water levels have fluctuated rapidly and suddenly, causing serious environmental and economic damages and adversely affecting oil and gas exploration, agriculture and fishing as well as areas contaminated by nuclear wastes. The instrumental record (since 1837) indicates a $3 \mathrm{~m}$ change with a sharp drop between 1930 (26m below sea level or bsl) and 1977 (29m bsl), followed by a sharp increase until $1995(-26.5 \mathrm{~m})$, and followed by a presentday possible stabilisation at $27 \mathrm{~m}$ bsl (Cazenave et al., 1997; Giralt et al., 2003; USDA, 2006; Leroy et al., 2006). The precise causes of these changes are not well deciphered yet. Climate, human impact and tectonic events (in sequence of decreasing likelihood) are believed to have interacted to influence CS levels (e.g. Shiklomanov et al., 1995; Froehlich et al., 1999). The sea-level fluctuations during the Holocene have been reconstructed in different investigations, but no consensus has arisen: amplitude and timing of the events vary dramatically between authors (e.g. Mamedov, 1997; Rychagov, 1997; Hoogendoorn et al., 2005).

The vegetation history of the area around the CS is equally poorly known. Moreover the few works that exist are published mainly in Russian. This vast region remains a gap in the Global Pollen Database and makes past climate modelling less robust. Palaeovegetation reconstructions in this region are therefore ground breaking.

Organic-walled dinoflagellate cysts (dinocysts) found in the CS have been described in Marret et al. (2004). These microfossils are nowadays increasingly used to reconstruct salinity changes, as the tolerance range of many species is relatively well known (e.g. Wall et al., 1977; Dodge and Harland, 1991; de Vernal et al., 1994; Marret and Zonneveld, 2003).

Furthermore, quantitative reconstructions of salinity have been obtained for a number of marine records from the Northern Hemisphere (de Vernal et al., 2005). The dinocyst record of the CS has remained poorly known until recently and is mostly used for the stratigraphy of oil wells. No Holocene diagrams of the dinocyst assemblages have been published yet. Many forms, species and even genera had not been described before the recent works of Marret et al. (2004). Since the taxonomy has been established, it has become possible to investigate sedimentary sequences to derive palaeoenvironmental changes. Dinocyst assemblages, cyst morphology and endemism may provide information about the impact of various environmental parameters and a basis for palaeoenvironmental reconstructions.

Based on sediment cores from the second half of the Holocene in the south and the middle basins of the CS, the aims of this investigation are to use 1) new data from pollen, spores and other microfossils to reconstruct palaeovegetation and taphonomy; and 2) new dinocyst assemblages to reconstruct changes in lake levels, mostly via salinity changes.

\section{Fig. 1}




\section{Study area}

The Black, Caspian and Aral Seas constitute relics of the Paratethys basin. Their relative isolation from each other after the closing of the Tethys led to different physical and biological conditions in each basin.

\subsection{Geographical setting, climate and vegetation}

The relief around the CS is roughly of two types: low lands in the northern half and the whole of the east side of the CS and high mountains in the south-west corner (the Lesser and Greater Caucasus Mountains) and the south (the Elburz Mountains).

Because of its great meridional extension, the CS straddles several climatic zones (Kosarev, 2005). The northern part of the drainage basin lies in a zone of temperate continental climate with the Volga catchment well into the humid mid-latitudes. The western coast features a moderately warm climate, while the southwestern and the southern regions fall into a subtropical humid climatic zone. The eastern coast has a desert climate.

Vegetation around the CS consists in the east of a northward gradient from desert (Chenopodiaceae and Artemisia) to steppe (Artemisia and several species of Gramineae): Irano-Touranian in the south-east (summer rainfall and cold winters) and Kazakho-Dsungarian in the west, north and north-east (winter rainfall) (Fig. 5.1 of Walter and Breckle, 1989). These authors mention freshwater holes in the desert between the Aral Sea and the CS with Populus, Elaeagnus, Salix and Alnus, as well as Calligonum and Tamarix. A very diverse vegetation including vast mesic and altitudinal forests has developed in the two mountain ranges (Fig. 10.17 of Walter and Breckle, 1989), even with refugial areas for some European species such as Parrotia persica (Leroy and Roiron, 1996). Today the biogeographical distribution of $P$. persica is reduced to the coastal area south of the CS and to the Caucasus up to $1500 \mathrm{~m}$ altitude, where the tree lives in a climate mild and humid all the year round (Leroy and Roiron, 1996; Binka et al., 2003).

According to Walter and Breckle (1989), the vegetation of the Volga lowland belongs to the Kazakho-Dsungarian desert belt up to $48^{\circ} \mathrm{N}$, and a semi-desert up to $50^{\circ} \mathrm{N}$. The Volga delta is dominated by freshwater wetlands with a Phragmites and Typha cover. Few tree species only are present in the delta itself: Salix, Tamarix, Ulmus and Populus (Labutina et al., 1995). Other tree species are only encountered further north (Walter, 1974).

\subsection{Hydrological setting}

The CS is the world's largest lake in terms of both area and volume, extending $35-48^{\circ} \mathrm{N}(>1000 \mathrm{~km})$ and $47-55^{\circ} \mathrm{E}$. The altitude of the surface was at $27 \mathrm{~m}$ bsl in 1994 (date of the coring campaign). Three basins divide the sea, becoming deeper southwards: the northern basin $\left(80,000 \mathrm{~km}^{2}\right)$ with an average depth of 5-6m and a maximum depth of $15-20 \mathrm{~m}$; the middle basin $\left(138,000 \mathrm{~km}^{2}\right)$ with an average depth of $175 \mathrm{~m}$ and a maximum depth of $788 \mathrm{~m}$; and the southern basin $\left(168,000 \mathrm{~km}^{2}\right)$ with an average depth of $325 \mathrm{~m}$ and a maximum depth of $1025 \mathrm{~m}$ (Fig. 1). The southern basin holds more than $65 \%$ of the Caspian water.

The CS drainage basin covers about 3.1 million $\mathrm{km}^{2}$. Water inputs comprise river discharges of the Volga (contributing up to $80-85 \%$ of the total), Kura, Ural and Terek Rivers (Rodionov, 1994). A series of smaller rivers bring water from the western and southern sides of the CS, whilst the river drainage from 
the eastern side of the CS is today inactive. This asymmetric pattern of river inflow and the gradient in evaporation induce a North-South positive gradient of water salinity, from freshwater salinity in the north basin to an almost homogeneous $12.5-13.5$ surface water salinity (salinities are given in psu) in the middle and south basins. In the south basin, seasonal salinity changes are less than $~ 0.2-0.4$. Mean annual salinity increases from the surface to the bottom waters by 0.1 to 0.3 (Zenkevitch, 1963; Kosarev and Yablonskaya, 1994).

A complex current pattern in the middle and south basins results in a surface cyclonic gyre (Zenkevitch, 1963). There is always a very good vertical mixing of the water masses, especially in winter sometimes enabling the ventilation of the near bottom layers. Surface waters of the south Caspian basin are near oxygen saturation in summer and slightly supersaturated in winter: mean values of 94 and 104\% respectively are reported in Zenkevitch (1963). According to this author, the dissolved oxygen content would decrease through depth: $~ 50 \%$ saturation at $200 \mathrm{~m}$ depth and less than $10 \%$ below $600 \mathrm{~m}$, but anaerobic conditions are never reached, even in the deepest waters. Notable fluctuations of the dissolved oxygen content are observed at different timescales: seasonal variations related to photosynthetic processes and water temperature, and annual to decadal variations in the convective water mixing intensity (Bordovsky, 1986; Kosarev and Yablonskaya, 1994). Most nutrients enter the CS in the northern basin via the Volga River. Today, the relatively low nutrient levels in the upper $100 \mathrm{~m}$ are further depleted by phytoplankton activity, but the nutrient concentrations increase with depth. Concentration of nutrients in the northern basin is presently lower than in the pre-regulation of the Volga River in the 1950s, except for the silicate group (Kosarev and Yablonskaya, 1994).

The CS waters flow out into the basin of the Karabogaz Gol (KBG) (Bortnik, 1991; Leroy et al., 2006), an eastern extension of the middle basin. The KBG basin (which has no outflow) thus serves as an evaporator.

Connections with adjacent seas have repeatedly taken place through fluctuating lake levels, tectonics, or human activities during the last millennia. The melting of the ice cap and the re-routing of north flowing rivers to the south accelerated a water transfer from the north (River Volga and Aral Sea/Uzboy pass) to the CS and then to the Black Sea.

In the Holocene, the Volga has built a delta in the north basin, extending as far as the north of the middle basin at times.

Past connections between the Azov Sea (Black Sea) and the CS have taken place via the Kuma-Manych depression (now up to $26 \mathrm{~m}$ asl) and the lower Don River. Evidence from deposits in the lower Volga River suggests that the last overflow from the CS lasted from $16-11{ }^{14} \mathrm{C}$ ka BP (19 to 13 cal. ka BP) with a brief interruption at $14-13{ }^{14} \mathrm{C}$ ka BP (Leonov et al., 2002). The deposition of red clays from the CS in the Black Sea shows that the most recent connection with the Black Sea is dated back to ca $13{ }^{14} \mathrm{C}$ ka BP (ca 15.5 cal. ka BP) (Bahr et al., 2005). Some later connections are however possible because widespread invasion from the Black Sea to the CS by the mollusc, Cerastoderma, occurred in the Middle Holocene (Grigorovich et al., 2003), although earlier dates are also quoted $\left(8-6{ }^{14} \mathrm{C}\right.$ ka BP; Tarasov et al., 1994). Transport by humans cannot however be totally excluded. 
The Uzboy River reached the CS $100 \mathrm{~km}$ south of the KBG in the Krasnovodsk Bay in the Late Pleistocene and episodically in the Holocene, the last time being in the $16^{\text {th }}$ century AD (Létolle, 2000). Human intervention is likely over the last millennia. The Uzboy brought a considerable supply of freshwater to the south basin. The lower section of the Uzboy River received water from the Amu-Daria and the Sarykamysh River directly from the TienShan, hence from a drainage basin under a climate totally different from that of the Volga River basin (Ferronsky et al., 1999). The palaeo-Amu-Daria has left traces of a powerful Pliocene delta in the bathymetry.

Cerastoderma glaucum most likely penetrated the Aral Sea from the CS during a period of highstand and connection via the Uzboy valley (Tarasov et al., 1994). This mollusc is reported in the Aral Sea at $5800-5250{ }^{14} \mathrm{C}$ yr BP. Subsequent high lake levels are also described 4475-3825, 1500-1175 and 250-0 ${ }^{14} \mathrm{C}$ yr BP.

The Apsheron sill separates the south basin from the middle basin with water depths of ca $80 \mathrm{~m}$. Traces of an ancient river are noted by Ferronsky et al. (1999). When the CS level is low this threshold creates a pronounced split between the two water bodies. Kuprin et al. (2003) propose that the two basins were separated until as recently as the Late Holocene. Following this recent tectonic submergence, an overflow from the middle to the south CS basin occurred (Kuprin, 2002).

\subsection{Hydrobiological setting}

Owing to its isolation, the CS shows a high endemism level (e.g. Dumont, 1998; Grigorovich et al., 2003; Marret et al., 2004).

The CS biota ranges from freshwater to brackish and to euryhaline types, with species of freshwater origin tolerating salinities up to 13 and species of marine origin tolerant of salinities down to 13 (Dumont, 1998). In general, marine species comprise $72 \%$ of the zooplankton. Surveys of the surface water of the CS have recorded about 440 phytoplanktonic species, the northern basin containing the greatest diversity (Kasymov and Rogers, 1996). Surveys in the 1960s and 1970s showed that dinoflagellates composed $9 \%$ of the phytoplankton population, whereas a recent survey (2001) indicates that almost half of the population consist of dinoflagellates (Kideys et al., 2005). However, this survey, before springtime, does not indicate any occurrence of Gonyaulax species. Bulatov (pers. com. and Leroy et al., 2006) counts 25 species, including four cyst-forming species, Gonyaulax digitalis, Gonyaulax spinifera, Lingulodinium polyedra and Preperidinium meunieri. Only about $20 \%$ of dinoflagellate species produce an organic-walled cyst that is well preserved in sediment, under anoxic conditions (Head, 1996). Evidence from the cyst population in recent sediments (e.g. Marret et al., 2004), shows the origin of the species is mixed, with Lingulodinium machaerophorum (cyst of $L$. polyedra) from the Atlantic-Mediterranean realms, cysts of Pentapharsodinium dalei from the sub-Arctic region, and Spiniferites cruciformis and Pyxidinopsis psilata from the Black Sea.

\subsection{Holocene fluctuations and their possible causes}

Fluvial influx to the CS, hydrometeorological conditions over the sea and bottom morphology changes are the main factors that control the seawater characteristics. Transgressions are usually accompanied by freshening of water masses and cold climate while regressions primarily correspond to 
increased salinities and warm climate (Chalié et al., 1997; Ferronsky et al., 1999; Ryan et al., 2003). Sequence stratigraphy in the productive layers of the Pliocene and Pleistocene has shown that river deltas (Volga, Kura and AmuDaria) have prograded during sea-level highstands (Abreu et al., 2006). At the end of the Pleistocene, large ice-dammed freshwater lakes formed along the southern edge of the Eurasian ice sheet (Grosswald, 1993; Mangerud et al., 2004). The timing of these palaeolakes' development is poorly known. Their drainage into the CS caused the Late Pleistocene Khvalynian highstand (50m asl) (Kroonenberg et al., 1997; Rhychagov, 1997). Some authors consider the last part of the Late Khvalynian highstand (between 0 and $20 \mathrm{~m} \mathrm{bsl}$ ) as already Holocene (Svitoch, pers. comm.). The following regression (the Mangyshlak; see discussion in Kroonenberg et al., 1997) is however considered to have taken place at ca $11-8.6{ }^{14} \mathrm{C}$ ka BP with a decrease of the level to possibly $80 \mathrm{~m}$ bsl. This regression is caused by the decrease of meltwater availability and by a dry climate. It is during this dry period that the Amu-Daria would have switched its flow from the south CS basin to the Aral Sea (Boomer et al., 2000).

In the most recent analyses, the beginning of the Neocaspian phase (the Holocene after the Mangyshlak lowstand) becomes increasingly younger and starts well into the Holocene (Kroonenberg et al., 1997). Svitoch (pers. comm., 2006), after reviewing radiocarbon dates of coastal deposits, even suggests that the Neocaspian phase (characterised by Cerastoderma glaucum) starts after $3.9{ }^{14} \mathrm{C}$ ka BP with an earlier high level, the Gousan at 6.4-5.4 ${ }^{14} \mathrm{C}$ ka BP. The preceding high phase (8.6-7.3 ${ }^{14} \mathrm{C}$ ka BP) is attributed to the Late Khvalynian on the base of its mollusc assemblages. During the Neocaspian phase period, the sea levels are generally moderately high with some fluctuations, whose number and timing deeply diverge between authors (e.g. Rychagov, 1997; Mamedov, 1997). A more consensual reconstruction exists around the last regression, the Derbent regression $\left(1.2-1 \mathrm{ka}{ }^{14} \mathrm{C} \mathrm{BP}\right)$ which was quite pronounced, down to $34 \mathrm{~m}$ bsl at least and corresponds to the Middle Ages (Hoogendoorn et al., 2005).

From the meteorological point of view, CS levels are directly influenced by precipitation over the Volga drainage basin (Arpe et al., 2000; Arpe and Leroy, in press). Over the $20^{\text {th }}$ century, a connection between CS levels and the El Niño Southern Oscillation has been highlighted, but not with the North Atlantic Oscillation (Arpe et al., 2000; Arpe and Leroy, in press). During glacial periods, this simple relationship is complicated by a large influx of meltwater (including via rivers now dry) originating from the North of the CS catchment area (Grosswald, 1993) and climatic feedbacks.

\section{Previous studies in the area}

\subsection{Pollen}

Pollen analyses on Holocene CS sediment have remained very scarce until now. As part of an INCO-Copernicus project, some pollen analyses have been performed on long cores (c. $10 \mathrm{~m}$ ) from the south and the middle basin covering from ca 24 to ca $5.5 \mathrm{ka} \mathrm{BP}$. The very low time resolution reached for the Holocene, the very low pollen counts and the probable lack of core overlap with the sequences presented here do not enable comparisons (Kuprin and Rybakova, 2003; Seret G., pers. com.). An earlier extended abstract (Leroy et al., 2000) briefly presented pollen and dinocyst data for a 
short core (CP14), but with a chronology now revised. A few disparate pollen spectra by Rybakova from the north basin are discussed in Bezrodnykh et al. (2004).

A more detailed diagram exists for the Holocene of the lower Volga $\left(46.22^{\circ} \mathrm{N}\right.$, $42.62^{\circ} \mathrm{E}$ ) with five radiocarbon dates (Bolikhovskaya, 1990). A diagram covering the last 200 years is available for the KBG (Leroy et al., 2006). During periods of higher water levels, the KBG is surrounded by a steppe-like vegetation, whereas during periods of low water levels, it is more like desert with the emerged land areas colonised by Chenopodiaceae. In addition to the surface samples of Tarasov et al. (1998), some surface pollen samples are now available for the Anzali lagoon, on the coast of Iran (Kazancl et al., 2004) and for the Aral Sea (Leroy et al., 2006).

\subsection{Dinocysts in the Caspian Sea and neighbouring seas}

The dinoflagellate cyst diversity found in central Asian seas has many species in common and shows a decrease eastwards. An increase in morphological diversity (correlated to a wider range of salinities encountered) was also detected (Marret et al., 2004).

For the whole of the CS, only surface samples have been published (Marret et al., 2004), including some from the Anzali lagoon (Kazancı et al., 2004). A record of the last 200 years has been published for the nearby KBG (Leroy et al., 2006) and, although the species list of the KBG is similar to that of the CS, the assemblages are dominated by a form of Lingulodinium machaerophorum (form A) and by Spiniferites belerius. This differentiates completely the KBG sequence from the sequences presented here. A sequence covering the last 2000 years (Sorrel et al., 2006) from the Aral Sea is characterised overall with low diversity, high levels of $I$. caspienense, accompanied by Protoperidinium species and $L$. machaerophorum. The fluctuations in $L$. machaerophorum abundance were linked with those of the sea level: lower sea level resulted in more saline conditions, hence providing an environment favourable for the growth of $L$. machaerophorum.

The pioneering work of Wall et al. (1973) and Wall and Dale (1973) in the southern Black Sea basin enabled the use of dinocysts for semi-quantitative reconstructions of past salinity changes. Since then, a number of studies have documented the Holocene dinocyst record (e.g. Bozilova et al., 1997; Mudie et al., 2002, 2004, in press; Atanassova, 2005). Furthermore, in order to characterise the exchanges between the Mediterranean-Marmara-Black Seas during the last $30 \mathrm{ka}$, in particular during the early Holocene, a multiproxy approach has documented outflow phases of the Black Sea (e.g. Aksu et al., 2002; Hiscott et al., 2002, 2006, in press).

\section{Materials and methods}

\subsection{Coring}

Cores (140 to $182 \mathrm{~cm}$ long) have been taken in the south basin, the middle basin and the northern part of the middle basin during a French-Russian oceanographic cruise (August 1994), on board a Russian military ship, rented for the sea cruise (Fig. 1). Core locations were in deep water, and were chosen to avoid direct river influence (CP14, 330m; CP18 480m; and CP21 $460 \mathrm{~m}$ depth, Fig. 1 and appendix 1). Three coring techniques were combined to recover complete sections for the Late Pleistocene and the Holocene. Long 
cores (ca 10m) were obtained using a Kullenberg corer (not presented in this paper). The uppermost part is usually lost during the coring process. The Pilot cores, ca 90 to $200 \mathrm{~cm}$, have also lost the more surficial sediment during the coring process (Fig. 2). The Usnel box cores (50cm thick) contain the watersediment interface. The cores (more details in appendix 1) are kept in a repository with a cool room.

\subsection{Lithological and mineralogical analyses}

Carbonate contents (cores CP14, CP18 and CP21) have been obtained by the Bernard volumetric method.

Special attention was paid to the carbonate mineralogy, since radiocarbon dates were performed on bulk carbonates. The authigenic carbonates being impossible to physically separate from the detrital ones (when present), detailed X-ray diffractometry (XRD) analyses were carried out, as a helpful tool to determine the origin of the carbonates, and the relative proportions of authigenic versus detrital carbonate phases. The calcite crystallinity index can be derived from the XRD (104) peak width at half-height; the Mg-content can be inferred from the deviation of the (116) XRD peak. A high crystallinity index and a low magnesium content are two indicators of a detrital character, while low crystallinity index associated with high Mg-content reveals authigenic origin. For each sample, this enables the correction of the ${ }^{14} \mathrm{C}$ activity of bulk carbonates, and the calculation of the ${ }^{14} \mathrm{C}$ activity of the authigenic fraction, assuming that detrital carbonates contain "dead" carbon only. Such a correction was applied to Holocene Tibetan lakes, where corrections led to the identification of both a valid radiocarbon chronology and valid stable isotopes records (Fontes et al., 1993).

\subsection{Dating methods: radionucleides and radiocarbon}

${ }^{210} \mathrm{~Pb},{ }^{226} \mathrm{Ra}$ and ${ }^{137} \mathrm{Cs}$ records were obtained from the Usnel box-core US02 (south basin) sub-sampled on board with PVC tubes. Samples were analysed every $\mathrm{cm}$ for both ${ }^{210} \mathrm{~Pb}$ and ${ }^{137} \mathrm{Cs}$ in the top $10 \mathrm{~cm}$, then every $2 \mathrm{~cm}$ down to $16 \mathrm{~cm}$. A sample at $22 \mathrm{~cm}$ reaches background values. Dry samples were measured with a very low-background, high efficiency well-type detector settled in the underground laboratory of Modane in the French Alps (Reyss et al., 1995) where $1700 \mathrm{~m}$ of rock overburden reduces the cosmic radiation by 6 orders of magnitude.

Samples for radiocarbon dating were taken in the three cores directly after core opening and subjected to the standard chemical protocol for AMS ${ }^{14} \mathrm{C}$ activities and associated ${ }^{13} \mathrm{C}$ contents. Graphite sources were prepared in Orsay, and counted with the accelerator mass spectrometer of Gif-sur-Yvette (TANDETRON). Analytical uncertainties, including laboratory errors, are \pm 0.1 $\%$ for $\partial^{13} \mathrm{C}$ and between 0.5 and 0.8 pMC for ${ }^{14} \mathrm{C}$ activity. Two types of corrections had to be applied to the apparent ages inherent to the CS. The first correction of the measured AMS ${ }^{14} \mathrm{C}$ activities to be considered is linked to the apparent ${ }^{14} \mathrm{C}$ activity $\left(\mathrm{A}_{0}\right)$ of the TDIC of the modern sea surface water. For the three samples from each part of the Caspian basin (i.e. North, Central and South), results have highlighted discrepancies between the existing ${ }^{14} \mathrm{C}$ activity of the surface water and that of atmospheric $\mathrm{CO}_{2}(\sim 117$ pMC at sampling time) up to $\Delta=8 \%$. The ${ }^{14} \mathrm{C}$ activity of surface water of the northern basin is 109, the middle basin 109/109.5 and the southern basin 108. 
A second correction is based on the semi-quantitative analyses of the sample mineralogical compositions with the measurement of the height $(\mathrm{H})$ of the 001 main peaks, multiplied by the width at half height $\left({ }^{1 / 2} \mathrm{~b}\right)$. Each reference peak is then given a specific coefficient $(F)$ taking into account the crystallinity of the mineral (Holtzapffel, 1985).

and

$$
\begin{aligned}
A & =(H * 1 / 2 b) / F \\
A(\%) & =A /[A+B+C+\ldots]
\end{aligned}
$$

with $\mathrm{F}$, equal to 0.1 for clays, 1.45 for quartz, and 1.0 for feldspars, calcite, $\mathrm{Mg}$-calcite and dolomite. The measured AMS ${ }^{14} \mathrm{C}$ ages and associated ${ }^{13} \mathrm{C}$ contents have been corrected as follows:

${ }^{* 13}$ C contents: $\quad d_{m}=X_{d}{ }^{*} d_{d}+(1-X)_{a}{ }^{*} d_{a}$

${ }^{*}{ }^{14}$ C activities: $\quad A_{m}=X_{d}{ }^{*} A_{d}+(1-X){ }_{a}{ }^{*} A_{a}$

with $d_{a}$ and $d_{d}$, stable isotope contents of the authigenic and detrital fractions respectively; $X_{a}$ and $X_{d}$, \% of authigenic and detrital fractions respectively versus total carbonate fraction $\left(X_{a}+X_{d}=1\right) ; A_{a}$ and $A_{d},{ }^{14} C$ activities of the authigenic and detrital fractions respectively. Assuming that the radiocarbon activity of the detrital fraction $A_{d}$ equals 0 pMC, equation (2) becomes:

And then:

$$
\mathrm{A}_{\mathrm{a}}(\mathrm{pMC}) \sim \mathrm{A}_{\mathrm{m}} / \mathrm{X}_{\mathrm{a}}
$$$$
{ }^{14} \mathrm{C} \text { ages (in yr BP) }=\mathrm{T} / \operatorname{Ln}(2){ }^{\star} \operatorname{Ln}\left(\mathrm{A}_{0} / \mathrm{A}_{\mathrm{a}}\right)
$$

with $\mathrm{T},{ }^{14} \mathrm{C}$ half-life period (5730 $\left.\pm 30 \mathrm{yr}\right)$.

After the above-mentioned corrections, all the dates were converted to calendar ages according to the revised calibration program CALIB 4.4 (Stuiver et al., 1998; Stuiver and Reimer, 1998/2000; Table 1), and mean sedimentary rates were calculated on calibrated ages.

\subsection{Palynology}

The same samples, taken every $5 \mathrm{~cm}$ in cores CP14, CP18 and CP21, were used for all the pollen, spores and dinocyst analyses. Initial processing of samples (on average $1 \mathrm{ml}$ ) involved the addition of sodium pyrophosphate to deflocculate the sediment. Samples were then treated with cold hydrochloric acid (10\%) and cold hydrofluoric acid (32\%), followed by a repeat $\mathrm{HCl}$. The residual organic fraction was then screened through 120 and $10 \mu \mathrm{m}$ mesh sieves and mounted on slides in glycerol. Lycopodium tablets were added at the beginning of the process for concentration estimates. Pollen and spores percentages were calculated on the terrestrial sum (excluding aquatic, spores and unknown or unidentifiable pollen), which is usually 300 grains. Statistical analyses are made available by Psimpoll (Bennett, 2003). Zonation by cluster analysis (CONISS) after square root transformation was applied. The zonation, based only on terrestrial taxa, was calculated for the percentage diagrams. The dinocysts were counted at the same time as pollen and other microfossils. The sequence of taxa used in the diagrams represents an attempt to classify them by increasing salinities. The sum for percentages (between 52 and 2400, although an effort was made to reach a minimum of 100 ) is made of all dinocysts except Brigantedinium spp. (including all roundbrown specimens), because of its ubiquitous character and frequent dominance of the spectra. Brigantedinium is expressed as a percentage of the same sum as the other dinocysts. Brigantedinium is included only in the concentration diagram (in number of cysts per $\mathrm{ml}$ of wet sediment). The taxonomy of many dinocyst species has been established by Marret et al. 
(2004). A ratio pollen concentration on dinocyst concentration (P:D) has been calculated according to McCarthy and Mudie (1998).

\subsection{Taxonomy and ecological preferences}

The pollen and spores diagram also includes small macrophytic remains such as Ceratophyllum spines and Salvinia massulae. The Salviniaceae are freefloating aquatic ferns. They grow in quiet waters and on mud near sluggish river edges, occasionally forming a dense carpet on the water surface. Salvinia natans is a frequent macrophyte in the wetlands around the CS. Hence its presence, as broken massulae sometimes with spores, is considered as a sign of river transport to the coring site (as was done for Azolla in Leroy, 1992).

Some other microfossils, identified with the help of Van Geel's plates (van Geel, 2001), such as Cyanobacteria and Chlorophyceae, are given in the dinocyst concentration diagram, as they may offer clues regarding palaeoenvironments, especially palaeosalinities. The Prasinophytic phycoma of Pterosperma (usually around $14 \mu \mathrm{m}$ ) is what has been recorded as the acritarch Cymatiosphaera globulosa in the Black Sea (Colbath and Grenfell, 1995; Mudie et al., 2001). Incertae sedis $5 b$ and $5 d$ are probably also prasinophytic phycomas. They are nearly the same size as Pterosperma. Incertae sedis $5 \mathrm{~d}(15 \mu \mathrm{m})$ is smooth with a slightly thicker wall than the two others, while incertae sedis $5 b(11 \mu \mathrm{m})$ has a more or less dense cover of short hair, sometimes with bald patches. Concentricystes circulus is a palynomorph that is probably related to the Zygnemataceae. It is often considered as an indicator of river run-off into marine or lacustrine systems linked to periods of heightened soil erosion (e.g. Leroy, 1992).

Little information is available on taxonomy and ecological requirements of the dinocysts of the CS. The organic-walled cyst species encountered in recent sediments of the CS and adjacent water bodies (Marret et al., 2004) show a poor diversity (seven taxa with, for some, various forms). Recently described taxa, for which the ecology is hardly known, often dominate the assemblages. The dinocyst taxa and their ecology found in the sediment cores of this project are the following from likely less saline to more saline, as far as presently known:

- Pyxidinopsis psilata (= Tectatodinium psilatum) and Spiniferites cruciformis are dominant in early Holocene sediments from the Black Sea and have been related to slightly brackish conditions ( $<7)$ and usually cool waters (Wall et al., 1973; Mudie et al., 2001; Mudie et al., 2002). The scarcity of modern analogues does not permit the derivation of adequate constraints on the limits of their ecological affinities (Marret et al., 2004), nor the differentiation of separate ecological requirement for the two taxa. $P$. psilata has also been found in high abundance in recent sediments from the Baltic Sea, in the middle Baltic where salinity is around 7 , but not in the environment where salinity is below 3 (Dale, 1996). Here three forms of Spiniferites cruciformis (A, B and C) have been recorded separately (Marret et al., 2004). Mudie et al. (2001) attempted to relate different morphotypes of S. cruciformis with salinity conditions, based on the length of processes and shape of the body. $S$. cruciformis has also been observed in lakes. For example, it has been identified in the Lateglacial sediment of Lake Kastoria, Northern Greece (Kouli et al., 2001) where, howeve,r Mudie's Forms 4 and 5 were never seen. In 
addition, this taxon has been seen in the top $\mathrm{cm}$ of Lake Sapanca sediment cores (NW Turkey) (Leroy, personal observation).

- Caspidinium rugosum var. rugosum and C. rugosum: This is a new genus about which not much is known yet. It has been observed in the CS, the KBG and the Aral Sea (Marret et al., 2004; Leroy et al., 2006).

- Impagidinium caspienense: this is a new species whose ecology is unknown. The known species of Impagidinium are typically present in oceanic environments and do not tolerate salinities lower than 30 , usually ca 35 . The usual working hypothesis is to assume that the new Impagidinium species may have the same requirements. However because high percentages and concentrations have been obtained in the cores, with even a slightly higher representation in the two northern ones, I. caspienense must be a species of much lower salinities. It has also been observed in the surface sediment of the Anzali lagoon, Iran (Kazancı et al., 2004).

- Pentapharsodinium dalei is usually a sub-Arctic cyst, also found in the tropics in low abundance. It occurs in the Mediterranean and Black Seas, with an affinity for environments of strong seasonal thermal contrast. It tolerates a wide range of salinity, from 15 to 35 (Marret and Zonneveld, 2003). It is found in the ocean and on continental platforms.

- Lingulodinium machaerophorum, a common species in sediment from oceans and continental seas, has a relatively well-documented distribution. Its greatest abundance is often found in neritic environments, with winter seasurface temperatures above $12^{\circ} \mathrm{C}$. It is considered as an indicator of eutrophic conditions (Dale et al., 1999). This species is known for its euryhaline nature (8-40), often characterised with a strong morphological variability of the cyst shape and processes (Lewis and Hallett, 1997). Two forms of Lingulodinium machaerophorum (var. B and ss) have been recorded separately (Leroy et al., 2006). Its thecate form, L. polyedra, is never found where salinity is below 7 (Dale, 1996); and in culture, it does not grow in an environment where salinity is below 10 (Lewis and Hallett, 1997).

- Brigantedinium species, produced by Protoperidinium species, are ubiquitous in marine and continental sea sediments, from low to high latitudes, and from neritic environments to open ocean regions. Their abundance and preservation may be affected by oxic conditions (Zonneveld et al., 2001). They are often related to high nutrient richness or have an opportunistic behaviour.

Fig. 2

In US02 box core (Fig. 1), I. caspienense reaches the relatively high value of $49.4 \%$ (sum without Brigantedinium spp., see above) for a salinity of ca 13 . $P$. psilata has $0.6 \%$, S. cruciformis $8.0 \%$, I. rugosum rugosum $2.8 \%$, $P$. dalei cysts $26.7 \%$, L. machaerophorum $12.5 \%$ and finally Brigantedinium sp. (on the sum of the other dinocysts) $15.4 \%$.

\section{Results}

\subsection{Lithology, mineralogy and age-depth model}

A brief lithological description of relatively homogenous sediment of each core is provided along with the carbonate content. 
The core sediment CP14 $(140 \mathrm{~cm})$ consists of fine-grained carbonate mudstone, with alternation of black and grey layers, often scarcely visible all along the sequence. Between 122 and $100 \mathrm{~cm}$, the sediment is sometimes laminated. The high carbonate values fluctuate mildly between 42 and $53 \%$. Core CP18 (182cm-long) consists of a mud, texturally very homogeneous, with faint laminations. The carbonate content is low, between 6 and 13\%. The sediment is laminated at $180-150 \mathrm{~cm}$, mottled at $150-110$, with a darker lamination at $110-70 \mathrm{~cm}$, with 3 lighter zones at $97-89,87-82$ and $74-70 \mathrm{~cm}$, laminated at $70-43 \mathrm{~cm}$, slightly darker at $42-38 \mathrm{~cm}$ and again at $30-20 \mathrm{~cm}$. The top $20 \mathrm{~cm}$ are laminated. The sediment of core CP21 $(179 \mathrm{~cm}-\mathrm{long})$ is a mud. The carbonate content is between 9 and $16 \%$. The sediment is mottled, with darker-lighter alternation on a cm scale between ca 179 and ca $153 \mathrm{~cm}$. From ca 140 to ca $92 \mathrm{~cm}$, there is an alternation of 5 to $15 \mathrm{~cm}$ thick zones that are distinctly darker or lighter. It is laminated at $39-29$ and $22-18 \mathrm{~cm}$.

Fig. 3

At the time of core opening, many sections showed lamination, which disappeared rapidly after exposure to air. Jelinowska et al. (1999), working on magnetic characteristics and mineralogy of sediments in the long cores, suggested that the lamination results from diagenesis. Such lamination tends to form when the conditions are anoxic and when the water is less saline. Boomer et al. (2005) suggest that the bottom of the CS never became truly anoxic over the last $15 \mathrm{ka}$ and that the laminations may be formed by postdepositional processes.

Both the lithology and the carbonate content confirm that there is no overlap between the short pilot cores (this study) and the long Kullenberg cores (Chalié et al., 1997; Kuprin et al., 2003).

\section{Table 1}

The carbonate values of the south basin (core CP14) are in general much higher than for the middle basin (cores CP18 and CP21) (Fig. 3). Detrital carbonates are expressed as percents of total carbonates (Table 1). For the period of interest, results show that in the southern basin, detrital carbonates represent slightly less than $10 \%$ of the total carbonates (CP14); however, in the middle basin, the detrital portion usually represents more than $50 \%$ of the total carbonates (CP18). Note that in the latter case, the high detrital content is associated to much lower total carbonates contents than in the southern basin.

\section{Fig. 4}

Profiles of ${ }^{210} \mathrm{Pbexc}\left({ }^{210} \mathrm{~Pb}\right.$ total minus ${ }^{226} \mathrm{Ra}$ supported $\left.{ }^{210} \mathrm{~Pb}\right)$ and ${ }^{137} \mathrm{Cs}$ plotted against depth in the core are displayed in Fig. 4. The regression line for ${ }^{210} \mathrm{Pbexc}$ profile permits the calculation of a sedimentation rate of $2.0 \mathrm{~mm}$. $\mathrm{y}$ ${ }^{1}$ for the top $22 \mathrm{~cm}$ of sediment in the south basin. Considering this sedimentation rate, the ${ }^{137} \mathrm{Cs}$ peak corresponding to the 1963 maximum atmospheric fallout would be at $6.2 \mathrm{~cm}$. This peak is detected between 6 and $7 \mathrm{~cm}$ in the core. This validates the ${ }^{210} \mathrm{Pbexc}$ rate. The Chernobyl accident 
signature of 1986 would be detected at about $1.5-2 \mathrm{~cm}$ depth. On the profile, an increase of ${ }^{137} \mathrm{Cs}$ activity is detected slightly deeper, between 2 and $3 \mathrm{~cm}$. Such small differences are frequent in a water-rich sediment and could be related to minor disturbance during coring or a bioturbation effect (Legeleux et al., 1995). They have only a negligible impact on an otherwise coherent set of data.

The radiocarbon dating of core $\mathrm{CP} 14$ is relatively robust owing to the two corrections provided in the technique section (table 1). However it has been impossible to correct the dates of cores CP18 and CP21 owing both to their low total carbonates content and to their too large detrital carbonate content. Only an apparent age is available. This can be considered as a maximum value (older limit) for the age, since the bias due to a carbonate detrital content is always towards ageing. Figure 2 indicates that, although there is no precise chronology for the CP cores of the middle basin, there is clearly a higher sedimentation rate in this basin. Therefore although the three cores have similar lengths, the period represented in their sequence becomes much shorter northward.

An additional indirect argument for the ages of cores CP 18 and CP 21 can be found in the study of the long cores from the same basin (Figs. 1 and 2). The depth of the Pleistocene/Holocene boundary in the long cores is at ca 100$95 \mathrm{~cm}$ in the south basin, SR9402GS04 (Kuprin et al., 2003) and SR9402GS05 (SR01GS9405) (Chalié et al. 1997) and at ca $460 \mathrm{~cm}$ in SR9402GS19 (Kuprin et al., 2003) and in the middle basin at ca $560 \mathrm{~cm}$ in core SR01GS9418 (SR9409GS20) (Boomer et al., 2005). This and the apparent ages indicate that the sediment of CP18 and CP21 was most likely formed more recently than the mid-Holocene.

In the south basin where US02 and CP14 cores were taken, the sedimentation rate obtained by the radionuclide method is 10 times higher than that obtained by radiocarbon. This could be caused not only by an expected lack of compaction of the top tens of $\mathrm{cm}$ of sediment but also by a very recent (the last few centuries) increase of the sedimentation rate. In conclusion, core CP14 has the best chronology of the three cores. This core covers from 5450 to $770 \mathrm{cal}$. yr BP. The chronology of the two other cores cannot be established. It can just be suggested that their sediment covers a shorter time period (Holocene sedimentation rates from the middle CS basin are higher than in the southern one) and their bases are probably younger than the age at the base of CP14.

\subsection{Results of pollen and spores analyses}

Fig. 5

This section presents the diagrams zone by zone first for pollen and spores and then for dinocysts. In some cases the zonation obtained by CONISS (e.g. $1,2,3$ ) is complemented by a visual subdivision (e.g. a, b, c). Pollen concentrations, dinocysts concentrations and the ratio between these two concentrations $(P: D)$ are reported on figure 5 for the three cores CP14, CP18 and CP21. 


\subsubsection{Core CP14}

Fig. 6

In this core 28 samples were studied and 88 taxa were recognised. The sequence was divided in two main pollen zones (pz) (based on CONISS and 21 selected taxa) (Fig. 6). Overall the diagram is dominated by Amarantaceae-Chenopodiaceae (A-C), Pinus, Gramineae and Artemisia.

\section{pz14-1 (base to $112.5 \mathrm{~cm}$ )}

This zone is clearly characterised by higher values of Pinus (20-35\%), Compositae Tubuliflorae and Liguliflorae, psilate monolete and trilete spores, and a distinct presence of reworked elements especially towards the top. Massulae of Salvinia are observed throughout. Pz14-1 ends sharply.

pz14-2 (112.5cm to top)

This zone becomes taxonomically more diverse. It shows a clear and progressive development of pollen from several deciduous trees, such as Pterocarya, Carpinus betulus-t. and Alnus. Parrotia persica is observed occasionally. Artemisia and concentration reach maximal values in the last few samples (pz14-2c). Pinus percentages are generally lower than in the previous zone, except at 47.5 to $32.5 \mathrm{~cm}$ (pz14-2b), where there is also an increase of spores, Salvinia and a lower concentration.

\section{Interpretation of $\mathrm{CP} 14$}

The terrestrial vegetation is that of desert to semi-desertic landscape. The arboreal component is small and whose origins would be in the Caucasus Mountains and in the Elburz Mountain (Fig. 1). Lower pollen concentrations and higher percentages of transport-resistant pollen and spores as well as floating-fern remains (developing along rivers) are in evidence at the bottom of the diagram (and to a lower extent in pz14-2b), suggesting the strong influence of river transport. The P:D ratio (Fig. 5) is especially low in pz14-1 and $\mathrm{pz} 14-2 \mathrm{~b}$.

\subsubsection{Core CP18}

\section{Fig. 7}

36 samples were analysed, in which 99 taxa were identified, inferring two pollen zones based on CONISS and on 14 main taxa (Fig. 7). Overall

Artemisia, A-C and Gramineae dominate the rather homogeneous diagram. In the non-arboreal pollen (NAP), only Cyperaceae and Compositae Tubuliflorae are present almost continuously. Amongst the arboreal pollen (AP), Pinus, Quercus and Alnus are well represented, with continuous curves. Carpinus betulus-t. has less regular values. In the aquatic taxa, Typha-Sparganium and Salvinia are well illustrated. Sudden increases of Artemisia and of concentration at the transition between pz18-1 and pz18-2 (at $97.5 \mathrm{~cm}$ ) are accompanied by a decrease of Gramineae. Pz18-1 is also characterised by frequent pollen grains of Cerealia-t..

This diagram is interpreted as showing a typical of a semi-desert turning into a 
steppic environment (with at first a more productive steppe), reflecting a precipitation increase.

\subsubsection{Core CP21}

Fig. 8

37 samples were studied, including 116 taxa and defining three main zones based on CONISS and on 17 main taxa (Fig. 8). Overall A-C, Artemisia, Pinus and Gramineae dominate the diagram. Quercus, Cyperaceae and TyphaSparganium are continuously present with values of 6,3 and $1 \%$ respectively. Cerealia-t. pollen grains occur regularly.

pz21-1 (base to $93 \mathrm{~cm}$ )

Although not suggested by CONISS, this zone is best divided into two subzones. Pz21-1 has rather high values of Pinus (dominant) and Liguliflorae whereas Artemisia percentages remain rather low (<6\%). Reworked elements are abundant. In pz21-1b (126-93cm), several maxima are reached: Pinus (>40\%), various spores, reworked elements and Salvinia.

pz21-2 (93 to $57.5 \mathrm{~cm}$ )

This zone is transitional and is characterised by a maximum of $\mathrm{A}-\mathrm{C}$ and Ephedra, increasing values of Artemisia and decreasing values of Pinus.

pz21-3 (57.5cm to top)

Pollen grains from diverse deciduous trees (Alnus, Carpinus betulus-t., Corylus, Fagus) and from Artemisia are high in parallel to maximal concentrations.

\section{Interpretation of CP21}

The diagram shows a desert becoming a steppe. It is interrupted by a phase with river influence in pz21-1b (low P:D, Fig. 5).

A few grains of Parrotia persica have made their way so far north. The presence of this taxon indicates that a large part of the AP may have originated from the distant Caucasus and the Elburz mountains.

\subsection{Results of dinocysts analyses}

Overall the assemblages are all largely dominated by $I$. caspienense.

Brigantedinium spp. display progressively higher values following a gradient from the south to the north. The species diversity is similar in the three cores. The concentrations in dinocysts (Fig. 5) are fairly similar in the three cores, around 10,000 cysts per $\mathrm{ml}$. The concentration diagrams are also divided into three dinozones $(\mathrm{dz})$ with zone limits at the same depths as for the percentage diagram. See also table 3 for a summary.

\subsubsection{Core CP14}

Fig. 9

28 samples were studied (Fig. 9). 
dz14-1 (140-97.5cm): P. psilata and S. cruciformis

The dominance of $P$. psilata, $S$. cruciformis and $C$. rugosum var. rugosum is well established, with the continuous presence of $C$. rugosum and $I$. caspienense. Cysts of $P$. dalei remain rare. Dz14-1 ends sharply.

$d z 14-2$ (97.5- 47.5cm): I. caspienense

A pronounced dominance of $I$. caspienense with some $S$. cruciformis, $C$. rugosum and cysts of $P$. dalei is observed. This zone has the lowest concentration on average (Fig. 6). The concentrations of $l$. caspienense are similar in this zone and the following.

dz14-3 (47.5- top): I. caspienense with C. rugosum and L. machaerophorum A dominance of $I$. caspienense (65-80\%) and a maximum of $C$. rugosum (dz14-3b) with the presence of $S$. cruciformis (especially in the first three samples, dz14-3a), and cysts of $P$. dalei are noted. This zone is characterised by the continuous occurrence of $L$. machaerophorum (both forms), always in low abundance. In concentration (Figs. 5 and 9), the presence of cysts of $P$. dalei and of the two forms of L. machaerophorum is clear.

Interpretation of CP14

Dz14-1 reflects relatively fresh and cool waters while dz14-2 suggests more brackish conditions in surface waters. $P$. dalei percentage values are low in $\mathrm{dz14}-1$, possibly because the salinity of this zone is too low. Across dz14-3, there is a progressive increase of water temperature and/or trophic state. The occurrence of $L$. machaerophorum suggests that salinity has reached a minimum of 7-10 that could be related to a lesser influence of river discharge.

\subsubsection{Core CP18}

Fig. 10

This diagram is based on 36 samples (Fig. 10).

dz18-1 (from the base at 180 to $110 \mathrm{~cm}$ ): I. caspienense

It is very largely dominated by $I$. caspienense (75-92\%) with the continuous occurrence of cysts of $P$. dalei and the occasional presence of several other taxa.

dz18-2 (110-35cm): I. caspienense with L. machaerophorum

I. caspienense still dominates but there is abundance of the two forms of $L$. machaerophorum. In the second half $(\mathrm{dz18}-2 \mathrm{~b})$, I. caspienense values drop dramatically down to $30 \%$ whilst the two forms of $L$. machaerophorum peak. The values of Pterosperma clearly increase. Concentration values increase progressively throughout this zone (Fig. 5).

dz18-3 (35cm to top): I. caspienense

It is very similar to dz18-1, except the low abundance of Brigantedinium. $L$. machaerophorum $\mathrm{B}$ values decrease progressively. 


\section{Interpretation of $\mathrm{CP} 18$}

The percentage decrease of $I$. caspienense in zone dz18-2b is not genuine, a slight increase in its concentration is registered. The percentage decline is mostly due to the increase of $L$. machaerophorum. Some other microfossils also become more abundant at these depths.

The diagram indicates brackish waters with a slight increase of salinity above $110 \mathrm{~cm}$ and colder temperature below that depth. The maximum of dinoconcentration (dz18-2) and indicates a temporary higher productivity.

\subsubsection{Core CP21}

Fig. 11

The diagram of CP21 (37 samples) is relatively homogeneous with the same species as the two other Holocene diagrams. It is dominated by $I$. caspienense (70-85\%) (Fig. 11).

dz21-1 (base to $150.5 \mathrm{~cm}$ ): I. caspienense

This $\mathrm{dz}$ displays a maximum of $I$. caspienense, both in percentages and concentration (Fig. 5). All the other taxa are present but in much smaller amounts.

dz21-2 (150.5 to $91.5 \mathrm{~cm}):$ I. caspienense with S. cruciformis Slightly higher values of $S$. cruciformis (>10\%) occur in dz21-2. L. machaerophorum s.s. forms a small peak in the second part of dz21-2. Rare fossils of Concentricystes circulus are observed in dz21-2 and just above the transition to $\mathrm{dz21-3.}$

dz21-3 (91.5cm to top): I. caspienense with L. machaerophorum and cysts of P. dalei

Dz21-3 is characterised by higher values of cysts of $P$. dalei. In the lower part of dz21-3, C. rugosum values make two peaks, while $L$. machaerophorum $\mathrm{B}$ are higher in the upper part. Anabaena, Pediastrum, Pterosperma and Incertae sedis $5 \mathrm{~b}$ are abundant in dz21-3.

\section{Interpretation of CP21}

The diagram suggests a gradual increase in salinity conditions. The fluctuations observed in $L$. machaerophorum frequencies may reflect periods when salinity fluctuates in relation to river discharge.

\section{Discussion}

\subsection{Comparison of the three cores}

\section{Table 2}

Based on the pollen assemblages of the Lower Volga River (Bolikhovskaya, 1990), it is likely that the Volga delta and other river deltas have had little direct impact on the composition of the pollen diagrams presented here, even 
on the northernmost core (CP21). Most of the pollen grains are windtransported from a large area around the CS (Hooghiemstra et al., 2006; Mudie and McCarthy, 2006). To identify more clearly where from the windtransported pollen originated, present-day meteorological data have been used (Fig. 12, appendix 2). From the end of the winter to the beginning of the summer, the winds progressively shift from the west (February) to the SW (April). Then after May, which is a transition month (from SW to SE), the winds of June and July are mainly from the east and north-east. The wind pattern provides a good opportunity for the pollen grains of the forest of the south and south-west of the CS to be transported to the core locations in spring and it explains the non-concealment of the AP by the NAP pollen grains of the desert and the steppe that makes up most of the perimeter of the CS.

Fig. 12

The steppe vegetation (Artemisia) is more productive than that of the desert (A-C). This is reflected by high Artemisia percentages and concentration. The influence of trees growing on the slopes of the Caucasus and the Elburz can be recognised in the three cores. It is however in CP18 that the AP (UImusZelkova, Vitis, Fagus and Alnus), aquatics, Artemisia and total concentration are maxima. CP18 spectra are interpreted as emerging from the most humid vegetation type of the three cores. The core location is directly influenced by the forest vegetation, the local expansion of agriculture and the rainfall in the Caucasus. Throughout the diagrams (second part of the Holocene), only trivial $\mathrm{N}-\mathrm{S}$ fluctuations of the boundary between desert and steppe have been observed as well as only slight vertical movements of vegetation belts on the mountains. The smallness of these changes is perhaps due to the buffering of the marine sediment and the very large source area for the pollen.

However three similarly outstanding zones (pz14-1, pz14-2b and pz21-1b), indicate a strong bias of the spectra with over-representation of the most resistant pollen and spores, higher massulae of Salvinia (river sides) and low total concentration owing to fast sedimentation rates or dilution by minerals (summary in table 2). A shift from air transport to water transport (strong river inflow) best explains these spectra. Pollen and spores with resistant exines are preferentially preserved in soils, and during periods of soil erosion they can become incorporated into lake sediments via rivers (Wilmshurst and McGlone, 2005). Compared to the diagram of the KBG covering the last 200 years (Leroy et al., 2006), pollen zone 3, displaying intense reworking linked to water run-off, palynologically is very similar to those of that of pilot cores presented here. The same taphonomical process is the most likely cause. Precise palaeovegetation could not be reconstructed during these phases of strong river flow as the signal is biased by a different taphonomy.

\section{Table 3}

The successive zones of the three Holocene diagrams are summarised in table 3. The presence of recently discovered forms of dinocysts hinders a detailed palaeoecological reconstruction, as there is not as yet any 
information on their ecology. However the interaction between the diverse taxa and the comparison to other proxies allows some suggestions.

- The most common situation is that the assemblages are dominated by $I$. caspienense, a new species. This, by comparison to modern analogues, is believed to represent a situation similar to the modern brackish salinities. In addition, I. caspienense largely dominates most of the diagrams except when $P$. psilata is abundant. It is therefore reasonable to suggest that, since $P$. psilata is a less brackish species (as established in the Black and the Baltic Seas), I. caspienense is a more brackish one.

- Zone dz14-1 has high values of $S$. cruciformis with $P$. psilata, as is the case for $d z 14-3$ and dz21-2, but with only S. cruciformis and with relatively low values of it. These three outstanding zones have also in common higher dinoflagellate concentrations. The distinct expansion of low salinity taxa is also known for the Early Holocene of the Black Sea.

- L. machaerophorum shows several phases of noticeable development: $d z 14-3, d z 18-2$ and dz21-3. Overall its presence is more marked towards the core tops. This pattern suggests an overall increase in salinity in the CS.

- The ecology of $C$. rugosum and $C$. rugosum var. rugosum, both a new genus and new species, is harder to define: $C$. rugosum seems to fluctuate in the opposite way to cysts of $P$. dalei; while $C$. rugosum var. rugosum appears so far to have an undefined behaviour in relation to other taxa.

- An increase of Pediastrum boryanum percentages and an increase in the diversity of freshwater algae and "other" microfossils occur from the south to the north. This reflects the overall freshening role of the Volga River.

\subsection{Palaeoecological interpretation of all palynological indicators and proposed chronology}

Holocene environmental changes are deduced from some co-variations between pollen, spores and dinocyst assemblages.

1) Often high $I$. caspienense values are paralleled by high A-C percentages. This corresponds to an environment with brackish waters and desert (dry climate).

2) High L. machaerophorum B values often go with high Artemisia, high Gramineae and high pollen concentration. This illustrates a more productive aquatic and terrestrial environment with a steppe vegetation (slightly wetter climate).

3) Zones with high S. cruciformis values always go with high Pinus, high spores, low pollen concentrations and high dinoconcentrations. This indicates that the lowest salinities go with high nutrients and a strong river influence.

The ratio $P: D$ (based on concentration) has been used as an additional proxy to select between slightly different $p z$ and dz limits (based on percentages) in order to identify limits for the outstanding phases (Fig. 5). The phase in the lower part of core CP14 is therefore chosen to be at $140-97.5 \mathrm{~cm}$, taking into consideration the low P:D just above pz14-1. The limits of the phase in the upper part of CP14 remain at $47.5-32.5 \mathrm{~cm}$, despite a low $P: D$ for the sample just below. The limits of the phase in the middle of CP21 are confirmed at $126-93 \mathrm{~cm}$, despite an earlier start in the dinocyst assemblages.

The limits of some of these boundaries (pz14-1, dz14-1, and pz21-1b) are sharp at the time resolution of this study (in CP 14, $167 \mathrm{yr}$ between midsamples, less in the other two cores). Two types of environmental 
modifications can be inferred: a small salinity with a strong river flow (top phase of CP14 and the middle of CP21), and both a strong river flow and a distinct lowering of salinities (bottom of CP14) (table 4). The core in the centre of the middle basin does not show any similar changes perhaps because it is too far from rivers (high $P: D$ indicates strong aeolian transport) or because it is of a different age.

\section{Table 4}

The changes in core CP14 are relatively well dated. An age has been attributed to each zone limit by interpolation between two adjacent dates: the end of a first freshwater/river phase is at ca $3.9 \mathrm{cal}$. ka BP and a second phase, less important and shorter, at ca 2.1-1.7 cal. ka BP (Fig. 2). Cores CP18 and CP21 are poorly dated. Based on the earlier chronological discussion, there is a possibility that the slight freshening of the water in the middle of CP21 is close in age to that in the top part of core CP14.

\subsection{Lower salinities, river transport, CS levels and climate}

The three cores show a positive gradient of salinities from the north to the south, especially well seen in the 'other' microfossil assemblages. Such a difference between basins cannot be explained only by a difference between river inflow and evaporation, the sill between two basins must have played a role too. According to Kuprin (2002) and Kuprin et al. (2003), the Apsheron sill blocked the flow until late in the Neocaspian phase and has subsided only very recently owing to tectonic movement.

It is suggested here that for the second half of the Holocene, the phases of low salinity/strong river transport correspond to periods of highstands. Bearing in mind the latter, and also that high sea-levels have often been correlated to cool periods, the following stratigraphic interpretation of the pollen-sporesdinocysts study is tentatively proposed.

The end of the first CP14 phase would correspond either to the end of the Gousan highstand (Rychagov, 1997), or even to the end of the Khvalynian highstand (Svitoch, pers. comm., 2006). The other highstands (middle of core CP21 and top of core CP14) may correspond to later minor highstands within the Neocaspian phase.

River input and low salinities in the south basin (pz14-1 and dz14-1) may be caused by an inflow from the Uzboy River, and to a lesser extent from the Kura River and the small rivers from the Elburz. The Uzboy River carries water either from high latitudes via the Aral Sea or from lower latitudes (TienShan) via the Amu-Daria. Deep-water conditions in the Aral Sea with a connection to the CS have occurred at ca $5800-5250$ and $4475-3825{ }^{14} \mathrm{C} \mathrm{yr}$ BP (Tarasov et al., 1994). This is compatible with the dates calculated for the end of the lower phase of CP14: 3.9 cal. ka BP.

For the later phase of slightly lower salinities and clear river input, in the south basin (2.1-1.7 cal. ka BP) and in the north of the middle basin, a stronger inflow of the Volga River (and of few other much smaller rivers from the north and the west) could also have played a role.

The periods of river input and lower salinities are most likely to correspond to a cooler regional climate with abundant meltwater inflow. A direct link between the CS record and Eurasian climate (Aral Sea: Boroffka et al., 2006; southern Russia and northern Kazakhstan: Kremenetski et al. 1997 and 1999; Issyk- 
Kul: Ricketts et al., 2001; lake Van: Wick et al., 2003) is not straightforward as regional effects (glacier melting, river re-routing or drying) are superimposed onto the Eurasian climate signal. In the Holocene, the Aral Sea and Lake Van (eastern Turkey) show a humid climate or high lake levels until c. $4000 \mathrm{cal}$. yr ago (Boroffka et al., 2006; Wick et al., 2003) that could correspond to the first period of river inflow and lower salinities of core CP14.

\subsection{Quantification of salinities and consequences for life near the Caspian Sea}

The reconstruction of palaeosalinity values for the CS is arduous because of the pre-eminence of a new genus and several new species. However the use of analogues and a comparison with the Black Sea may provide a guide towards some wide-ranging suggestions.

The modern assemblages are dominated by I. caspienense (e.g. $49.4 \%$ in US02) (Marret et al., 2004; Kazancı et al., 2004). By analogy, this suggests that the salinities of the I. caspienense phases were broadly similar to those of the present.

At the scale of the Black Sea during the Holocene, a comparison of the succession of the main dinozones displays some similarities to the CS. The dinocyst assemblage succession shows three main zones (Wall et al., 1973; Wall and Dale, 1973; Bozilova et al. 1997; Mudie et al., 2001, 2004, in press) for which a study combining oxygen isotopes and dinocyst assemblages has permitted the suggestion of palaeosalinity values. The three assemblages and associated salinities are: P. psilata - S. cruciformis lower than 7 (quasi freshwater, the new Euxinian period), L. machaerophorum - C. globulosa 7-18 (brackish, the Old Black Sea period) and L. machaerophorum - Peridinium ponticum 18-22 (euryhaline, the modern Black Sea period) (Atanassova, 1995; Mudie et al., 2001, 2004).

Therefore in the present CS diagrams,

a) Dz14-1 assemblages infer brackish salinities lower than 7;

b) The phases (such as dz14-2) dominated by I. caspienense, which are the longest, are probably broadly similar to the present, i.e. ca 13;

c) Dz18-2 and dz21-3 with Pterosperma and L. machaerophorum B resemble the Black Sea zone with C. globulosa and L. machaerophorum: hence salinities of 7-18 can be suggested. However the presence of freshwater algae in dz21-3 gives a mixed signal similar to that obtained in the Aral Sea (Sorrel et al., 2006). This complex signal has been explained there by the freshwater algae brought in by river discharge in a low level Aral Sea. It is therefore suggested that dz21-3 salinity corresponds to the lower end of the salinity range of the Black Sea assemblage.

Consequently, the more freshwater phases identified here have salinities that are acceptable for animal (but not for human) consumption. This must have had an impact on the population density along the coast, especially in the steppe and desert areas where sources of freshwater are very limited. The nomadic populations may have increased during those periods and followed migration routes close to the coast.

\section{Conclusion}

As the river input to the CS is one of the main factors influencing the sea level, if not the main one, it is crucial to demonstrate that palynology (both pollen-spores and dinocysts) is able to reconstruct past fluctuations of river 
inflow and salinities. Nowadays the Volga is by far the main river inflow. In the Holocene until a still undetermined time, the Uzboy River brought a large amount of water as well.

Despite difficulties with the chronological framework and the ecological interpretation of new dinocyst taxa, the following general points have been highlighted. The large difference in sedimentation rates between basins is confirmed, along with a gradient with lower salinities towards the north. Vegetation shows a mostly gentle fluctuation between desert and steppe, however with occasionally such an intense river influence that taphonomical bias precludes past vegetation reconstruction. The northern part of the middle basin and the south basin exhibit some variability of salinity and river inflow, whereas the core in the centre of the middle basin does not provide any information.

More precisely, the establishment of a diagnostic palynological tool for the normal mode of the CS (brackish lake) and an unusual mode (less brackish due to freshwater inflow) tested on three cores has produced three important results.

1. The salinity of the second half of the Holocene was mostly fluctuating around the present levels (13). This was interrupted by more freshwater phases with salinities below 7 . Such values are acceptable as drinking water for animals. Hence nomadic tribes and small settlements may have flourished.

2. A well-defined less brackish phase with important river inflow ends at ca 3.9 cal. ka BP. In CS stratigraphy it may be correlated to the end of the Gousan highstand, or alternatively to the end of the Khvalynian meltwater phase. The Uzboy River brought water to the south basin of the CS either from the north via the Aral Sea or from the south-east via the Amu-Daria. A second period of enhanced river inflow and highstand (2.1-1.7 cal. ka $\mathrm{BP})$ could correspond to one of the later highstands recognised in the Russian literature.

3. It is suggested that periods of less brackish waters and stronger river inflow correspond to a regionally cooler climate with abundant meltwater inflow.

\section{Acknowledgements}

This study has been conducted with the help of the European Contract INCOCopernicus "Understanding the Caspian Sea erratic fluctuations" $\mathrm{n}^{\circ} \mathrm{IC} 15$ CT96-0112. This was funded by the Centre National de la Recherche Scientifique in the frame of the CNRS-INSU-DYTEC (DYnamique de la Terre et du Climat) Programme (France). Our gratitude goes to F. Gasse, the project leader. Thanks are due to the French and Russian colleagues who organized and participated in the coring and the hydrological sea expedition of August 1994, especially P. Tucholka and V.I. Ferronsky, chief scientists. P.-J. Giannesini is the curator of the cores (Laboratoire de Géologie, Museum d'Histoire Naturelle de Paris, France) and kindly provided the carbonate data. We thank F. Guichard for fruitful discussions, A.S. Escudié for contribution to radiocarbon analyses, and $F$. Mélières for determination of detrital carbonates percentages and J.J. Motte for the drawing of figure 1. The palynological samples were treated in the UK (Queen's University of Belfast and Brunel University). M. Turner (Brunel University) has kindly revised the English of the 
manuscript. This article represents a contribution to the Dark Nature programme of ICSU and to IGCP 481 and 490 projects. 


\section{References}

Abreu, V., Nummedal, D., 2006. Miocene to Quaternary sequence stratigraphy of the south and central Caspian basins. In: Yilmaz, P.O., Isaksen, G.H. (Eds.), Oil and gas of the Greater Caspian area. Selected publications from the 2000 AAPG Istanbul Regional International Conference: AAPG Studies in Geology 55, pp. 1-22.

Aksu, A.E., Hiscott, R.N., Kaminski, M.A., Mudie, P.J., Gillespie, H., Abrajano, T., Yasar, D., 2002. Last glacial-Holocene paleoceanography of the Black Sea and Marmara Sea: stable isotopic foraminiferal and coccolith evidence. Marine Geology 190, 119-149.

Arpe, K., Bengtsson, L., Golitsyn, G.S., Mokhov, I.I., Semenov, V.A., Sporyshev, P.V., 2000. Connection between Caspian Sea level variability and ENSO. Geophysical Research Letters 27, 2693-2696.

Arpe, K., Leroy, S.A.G., in press. Impacts of global warming on the Caspian Sea level. Quaternary International. dx.doi.org/10.1016/j.quaint.2007.03.008

Atanassova, J., 1995. Dinoflagellate cysts of late Quaternary and recent sediments from the western Black Sea. Annual of the University of Sofia "St Kliment Ohridski", book 2, Botany 87, 17-28.

Atanassova, J., 2005. Palaeoecological setting of the western Black Sea area during the last 15000 years. The Holocene 15, 576-584.

Bahr, A., Lamy, F., Arz, H.W., Kuhlmann, H., Wefer, G., 2005. Late glacial to Holocene climate and sedimentation history in the NW Black Sea. Marine Geology 214, 4, 309-322.

Bennett, K., 2003. psimpoll and pscomb programs for plotting and analysis. Version psimpoll 4.10. www.kv.geo.uu.se/psimpoll.html

Bezrodnykh, Yu., Romanyuk, B., Deliya, S., Magomedov, R., Sorokin, V., Parunin, O., Babak, E., 2004. Biostratigraphy and structure of the Upper Quaternary deposits and some paleogeographic features of the north Caspian region. Stratigraphy and Geological Correlation 12, 1, 102-111.

Binka, K., Nitychoruk, J., Dzierzek, J., 2003. Parrotia persica C. A. M. (Persian witch hazel, Persian ironwood) in the Mazovian (Holsteinian) Interglacial of Poland. Grana 42, 227-233.

Bolikhovskaya, N.S., 1990. Palynological changes in the landscape of the lower Volga in the last 10000 years. In: Lebedev, L.I., Maev, E.G. (Eds.), Caspian Sea, problems of geology and geomorphology. Moscow, Nauka, pp. 52-68 (in Russian).

Boomer, I., Aladin, N., Plotnikov, I., Whatley, R., 2000. The palaeolimnology of the Aral Sea: a review. Quaternary Science Reviews 19, 1259-1278.

Boomer, I., von Grafenstein, U., Guichard, F., Bieda, S., 2005. Modern and Holocene sublittoral ostracod assemblages (Crustacea) from the Caspian Sea: a unique brackish, deep-water environment. Palaeogeography, Palaeoclimatology, Palaeoecology 225, 173-186.

Bordovsky, O.K., 1986. Changes in the Hydrochemical regime of the Caspian Sea. Priroda 4, 16-19 (in Russian).

Boroffka, N.,Oberhänsli, H., Sorrel, P., Demory, C., Wünnemann, B., Alimov, K., Baratov, S., Rakhimov, K., Saparov, N., Shirinov, T., Krivonogov, S. K., Röhl, U., 2006. Archaeology and climate: settlement and lake-level changes at the Aral Sea. Geoarchaeology 21, 7, 721-734. 
Bortnik, V.N., 1991. The water balance of the Bay of Kara-Bogaz-Gol under natural and controlled conditions. Trudy GOIN, 183, 3-18 (in Russian).

Bozilova, E., Atanassova, J., Filipova-Marinova, M., 1997.

Marinopalynological and archaeological evidence for the Lateglacial and Holocene vegetation in eastern Bulgaria. Annual of University of Sofia "St Kliment Ohridski", Faculty of Biology, Botany 2, 69-81.

Cazenave, A., Bonnefond, P., Dominh, K., Schaeffer, P., 1997. Caspian sea level from TOPEX/POSEIDON altimetry: level now falling. Geophysical Research Letters 24, 881-884.

Chalié, F., and the Caspian Sea INSU-DYTEC Program members 1997. The glacial-postglacial transition in the southern Caspian Sea. Comptes Rendus de l'Académie des Sciences de Paris 324, Ila, 309-316.

Colbath, G.K., Grenfell, H.R., 1995. Review of biological affinities of Paleozoic acid-resistant, organic-walled eukaryotic algal microfossils (including "acritarchs"). Review of Palaeobotany and Palynology 86, 287-314.

Dale, B., 1996. Dinoflagellate cyst ecology: modelling and geological applications. In: Jansonius, J., McGregor, D.C. (Eds.), Palynology: Principles and Applications. American Association of Stratigraphic Palynologists Foundation 3, USA, pp. 1249-1275.

Dale, B., Thorsen, T.A., Fjellså, A., 1999. Dinoflagellate cysts as indicators of cultural eutrophication in the Oslofjord, Norway. Estuarine, Coastal and Shelf Science 48, 371-382.

de Vernal, A., Eynaud, F., Henry, M., Hillaire-Marcel, C., Londeix, L., Mangin, S., Matthiessen, J., Marret, F., Radi, T., Rochon, A., Solignac, S., Turon, J., 2005. Reconstruction of sea-surface conditions at middle to high latitudes of the Northern Hemisphere during the Last Glacial Maximum (LGM) based on dinoflagellate cyst assemblages. Quaternary Science Reviews 24, 897-924.

de Vernal, A., Turon, J.-L., Guiot, J., 1994. Dinoflagellate cyst distribution in high-latitude marine environments and quantitative reconstruction of sea-surface salinity, temperature, and seasonality. Canadian Journal of Earth Science 31, 48-62.

Dodge, J.D., Harland, R., 1991. The distribution of planktonic dinoflagellates and their cysts in the eastern and northeastern Atlantic Ocean. New Phytologist 118, 593-603.

Dumont, H.J., 1998. The Caspian Lake: history, biota, structure, and function. Limnology and Oceanography 43, 1, 44-52.

Ferronsky, V.I., Polyakov, V.A., Kuprin, P.N., Lobov, A.L., 1999. The Nature of Variations in the Level of the Caspian Sea (Based on Bottom-Sediment Data). Water Resources 26, 6, 583 -596.

Fontes, J.C., Mélières, F., Gibert, E., Qing, L., Gasse, F., 1993. Stableisotope and radiocarbon balances of 2 Tibetan lakes (Sumxi Co, Longmu Co) from 13,000 BP. Quaternary Science Reviews 12, 875887.

Froehlich, K., Rozanski, K., Povinec, P., Oregioni, B., Gastaud, J., 1999. Isotope studies in the Caspian Sea. The Science of the Total Environment 237/238, 419-427.

Giralt, S., Julià, R., Leroy, S.A.G., Gasse, F., 2003. Cyclic water level oscillations of the KaraBogaz Gol - Caspian Sea system. Earth and Planetary Science Letters 212, 1-2, 225-239. 
Grigorovich, I.A., Therriault, T.W., Maclsaac. H.J., 2003. History of aquatic invertebrate invasions in the Caspian Sea. Biological Invasion 5,103115.

Grosswald, M., 1993. Extent and melting history of the late Weichselian ice sheet, the Barents-Kara continental margin. In: Peltier, W.R. (Ed.), Ice in the climate system. Nato ASI series, vol. I 12, Springer Verlag Berlin, pp $1-20$.

Head, M.J., 1996. Modern dinoflagellate cysts and their biological affinities. In: Jansonius, J., McGregor, D.C. (Eds.), Palynology: principles and applications, American Association of Stratigraphic Palynologists Foundation, Salt Lake City, vol. 3, pp. 1197-1248.

Hiscott, R.N., Aksu, A.E., Yasar, D., Kaminski, M.A., Mudie, P.J., Kostylev, V.E., MacDonald, J.C., Isler, F.I., Lord, A.R., 2002. Deltas south of the Bosphorus Strait record persistent Black Sea outflow to the Marmara Sea since $10 \mathrm{ka}$. Marine Geology 190, 95-118.

Hiscott, R.N., Aksu, A.E., Mudie, P.J., Kaminski, M.A., Abrajano, T., Yaşar, D., Rochon, A., 2006. The Marmara Sea Gateway since $16 \mathrm{Ka:}$ noncatastrophic causes of paleoceanographic events in the Black Sea at 8.4 and 7.15 ka. In: Yanko-Hombach, V., Gilbert, A.S., Panin, N., Dolukhanov, P., The Black Sea Flood Question: changes in Coastline, Climate and Human Settlement. Dordrecht, Springer, pp. 89-117.

Hiscott, R.N., Aksu, A.E., Mudie, P.J., Marret, F., Abrajano, T., Kaminski, M.A., Evans, J., Cakiroglu, A., Yasar, D., in press. A gradual drowning of the southwestern Black Sea shelf: evidence for a progressive rather than abrupt Holocene reconnection with the eastern Mediterranean Sea through the Marmara Sea Gateway. Quaternary International 168:19-34. Hoogendoorn, R.M., Boels, J.F., Kroonenberg, S.B., Simmons, M.D., Aliyeva, E., Babazadeh, A.D., Huseynov, D., 2005. Development of the Kura delta, Azerbaijan; a record of Holocene Caspian sea-level changes. Marine Geology 222-223, 359-380.

Hooghiemstra, H., Lézine, A.-M., Leroy, S.A.G., Dupont, L., Marret, F., 2006. Late Quaternary palynology in marine sediments: a synthesis of the understanding of pollen distribution patterns in the NW African setting. Quaternary International 148, 29-44.

Holtzapffel, L.T., 1985. Les minéraux argileux. Préparation, analyse diffractométrique et détermination. Publications de la Société Géologique du Nord, 12, 1-136.

Jelinowska, A., Tucholka, P., Guichard, F., Lefèvre, I., Badaut-Trauth, D., Chalié, F., Gasse, F., Tribovillard, N., Desprairies, A., 1998. Mineral magnetic study of Late Quaternary South Caspian Sea sediments: paleoenvironmental implications. Geophysical Journal International 133, 499-509.

Kasymov, A., Rogers, L., 1996. Ecological description of the southern Caspian Sea in the oil-field region of "Guneshly". Polish Ecological Studies 22, 3-4, 83-93.

Kazancı, N., Gulbabazadeh, T., Leroy, S.A.G., Ileri O., 2004. Sedimentary and environmental characteristics of the Gilan-Mazenderan plain, northern Iran: influence of long- and short-term Caspian water level fluctuations on geomorphology. Journal of Marine Systems 46, 1-4, 145168. 
Kideys, A.E., Soydemir, N., Eker, E., Vladymyrov, V., Soloviev, D., Melin, F., 2005. Phytoplankton distribution in the Caspian Sea during March 2001. Hydrobiologia 543, 159-168.

Kosarev, A.N., Yablonskaya, E.A., 1994. The Caspian Sea. SPB Academic Publishing, The Hague.

Kosarev, A.N., 2005. Physico-geographical conditions of the Caspian Sea. In: Hutzinger, $\mathrm{O}$. The handbook of environmental chemistry. vol. 5 Water pollution, part $\mathrm{P}$, Springer-Verlag, Berlin, pp. 5-31.

Kouli, K., Brinkhuis, H., Dale B., 2001. Spiniferites cruciformis: a freshwater dinoflagellate cyst. Review of Palaeobotany and Palynology 133, 273286.

Kremenetski, C., Chichagova, O., Shishlina, N., 1999. Palaeoecological evidence for Holocene vegetation, climate and land-use in the low Don basin and Kalmuk area, southern Russia. Vegetation History and Archaeobotany 8, 233-246.

Kremenetski, C., Tarasov, P., Cherkinsky, E., 1997. Postglacial development of Kazakhstan pine forests. Géographie physique et Quaternaire 51, 3, 391-404.

Kroonenberg, S.B., Rusakov, G.V., Svitoch, A.A., 1997. The wandering of the Volga delta: a response to rapid Caspian sea-level change. Sedimentary Geology 107, 189-209.

Kuprin, P.N., 2002. Apsheron threshold and its role in the processes of sedimentation and formation of hydrological regimes in the southern and middle Caspian basins. Water Resources 29, 5, 473-484.

Kuprin, P.N., Ferronsky, V.I., Popovchak, V.P., Shlykov, V.G., Zolotaya, L.A., Kalisheva, M.V., 2003. Bottom sediments of the Caspian Sea as an indicator of changes in its water regime. Water Resources 30, 2, 136153.

Kuprin, P.N., Rybakova, N.O., 2003. Analysis of palynological complexes of deep-sea sediments in the Middle and Southern Caspian. Water Resources 31,1, 1-9.

Labutina, I., Zhivogkiad, A., Gorbunov, A., Rusanov, G., Baldina, E., de Leeuw, J., 1995. The Astrakhanskiy Biosphere Reserve GIS. Part 3: Vegetation map. ITC Journal 3, 197-201.

Legeleux, F., Reyss, J.L., Schmidt, S., 1995. Particles mixing rates in sediments of the North-East Tropical Atlantic: evidence from ${ }^{210} \mathrm{Pbxs}$, ${ }^{137} \mathrm{Cs},{ }^{228} \mathrm{Thxs}$ and ${ }^{234}$ Thxs downcore distributions. Earth and Planetary Science Letters 128, 545-562.

Leonov, Yu.G., Lavrushin, Yu.A., Antipov, M.P., Spiridonova, E.A., Kuzmin, Ya.V., Jull, E.J.T., Burr, G.S., Jelinowska, A., Chalié, F., 2002. New age data on sediments of the transgressive phase of the Early Khvalyn transgression of the Caspian Sea. Doklady of RAS, Earth Science Section, 386, 7, 748-751.

Leroy, S.A.G., 1992. Palynological evidence of Azolla nilotica Dec. in Recent Holocene of eastern Nile Delta, and its environment. Vegetation History and Archaeobotany 1, 43-52.

Leroy, S.A.G., Marret, F., Gasse, F., Chalié, F., 2000. Understanding the Caspian Sea erratic fluctuations: palynological results from the south basin. ELDP-ESF meeting, Pallanza, Italy. 7-12 Oct. 2000. Terra Nostra 7, 45-49. 
Leroy, S.A.G., Marret, F., Giralt, S., Bulatov, S.A., 2006. Natural and anthropogenic rapid changes in the Kara-Bogaz Gol over the last two centuries by palynological analyses. Quaternary International 150, 5270.

Leroy, S.A.G., Roiron P., 1996. Final Pliocene macro and micro floras of the paleovalley of Bernasso (Escandorgue, France). Review of Palaebotany and Palynology 94, 295-328.

Létolle, R., 2000. Histoire de l'Ouzboï, cours fossile de l'Amou Darya synthèse et éléments nouveaux. Studia Iranica 29, 2, 195-240.

Lewis, J., Hallett, R., 1997. Lingulodinium polyedrum (Gonyaulax polyedra) a blooming dinoflagellate. Oceanography and Marine Biology Annual Review 2135, 97-161.

Mamedov, A.V., 1997. The Late Pleistocene-Holocene history of the Caspian Sea. Quaternary International 41/42, 161-166.

Mangerud, J., Jakobsson, M., Alexanderson, H., Astakhov, V., Clarke, G.K.C., Henriksen, M., Hjort, C., Krinner, G., Lunkka, J.-P., Moller, P., Murray, A., Nikolskaya, O., Saarnisto, M., Svendsen, J.I., 2004. Ice-dammed lakes and rerouting of the drainage of northern Eurasia during the last glaciation. Quaternary Science Reviews 23, 1313-1332.

Marret, F., Leroy S.A.G., Chalié, F., Gasse F., 2004. New organic-walled dinoflagellate cysts from recent sediments of central Asian seas. Review of Palaeobotany and Palynology 129, 1- 20.

Marret, F., Zonneveld, K.A.F., 2003. Atlas of modern organic-walled dinoflagellate cyst distribution. Review of Palaeobotany and Palynology 125, 1-200.

McCarthy, F.M.G., Mudie, P.J., 1998. Oceanic pollen transport and pollen:dinocyst ratios as markers of late Cenozoic sea level change and sediment transport. Palaeogeography, Palaeoclimatology, Palaeoecology 138, 187-206.

Mudie, P.J., Aksu, A.E., Yasar, D., 2001. Late Quaternary dinocysts from the Black, Marmara and Aegean Seas: Variations in assemblages, morphology and paleosalinity. Marine Micropaleontology 43, 155-178.

Mudie, P.J., McCarthy, F.M.G., 2006. Marine palynology: potentials for onshore-offshore correlation of Pleistocene-Holocene records. Invited paper. Transactions of the Royal Society of South Africa 61, 2, 139-157.

Mudie, P.J., Rochon, A., Aksu, A.E., Gillespie, H., 2002. Dinoflagellate cysts, freshwater algae and fungal spores as salinity indicators in Late Quaternary cores from Marmara and Black seas. Marine Geology 190, 203-231.

Mudie, P.J., Rochon, A., Aksu, A.E., Gillespie, H., 2004. Late glacial, Holocene and modern dinoflagellate cyst assemblages in the AegeanMarmara-Black Sea corridor: statistical analysis and re-interpretation of the early Holocene Noah's Flood hypothesis. Review of Palaeobotany and Palynology 128, 1-2, 143-167.

Mudie, P.J., Marret, F., Aksu, A.E., Hiscott, R.N., Gillespie, H., in press.

Palynological evidence for climatic change, anthropogenic activity and outflow of Black Sea Water during the late Pleistocene and Holocene: centennial- to decadal-scale records from the Black and Marmara Seas. Quaternary International 168: 73-90. 
Reyss, J.-L., Schmidt, S., Legeleux F., Bonte, P., 1995. Large, low background well-type detectors for measurements of environmental radioactivity. Nuclear Instruments and Methods A 357, 391-397.

Ricketts R.D., Johnson, T. C., Brown, E. T., Rasmussen, K. A., Romanovsky, V. V., 2001. The Holocene paleolimnology of Lake Issyk-Kul, Kyrgyzstan: trace elements and stable isotope composition of ostracods. Palaeogeography, Palaeoclimatology, Palaeoecology 176, 207-227.

Rodionov, S.N., 1994. Global and regional climatic interaction: The Caspian Sea experience. Kluwer Academic Press, Dordrecht.

Ryan, B.F., Major, C.O., Lericolais, G., Goldstein, S.L., 2003. Catastrophic flooding of the Black Sea. Annual Review of Earth Planetary Science 31, 525-554.

Rychagov, G.I., 1997. Holocene oscillations of the Caspian Sea and forecasts based on palaeogeographical reconstructions. Quaternary International 41/42, 167-172.

Shiklomanov, I.A., Georgievsky, V.Y., Kopaliani, Z.D., 1995. Water balance of the Caspian Sea and reasons of water level rise in the Caspian Sea. In: UNESCO (Ed.), UNESCO-IHP-IOC-IAEA Workshop on Sea level rise and the multidisciplinary studies of environmental processes in the Caspian Sea region. Intergovernmental Oceanographic Commission, Workshop Report N¹08 - Supplément, Paris (France), pp. 1-27.

Sorrel, P., Popescu, S.-M., Head, M.J., Suc, J.-P., Klotz, S., Oberhänsli, H., 2006. Hydrographic development of the Aral Sea during the last 2000 years based on a quantitative analysis of dinoflagellate cysts.

Palaeogeography, Palaeoclimatology, Palaeoecology 234, 2-4, 304-327.

Stuiver, M., Reimer, P.J., 1998/2000. CALIB 4.3 radiocarbon calibration program. The UW Quaternary Isotope Laboratory http://depts.washington.edu/qil/

Stuiver, M., Reimer, P.J., Bard, E., Beck, J.W., Burr, G.S., Hughen, K.A., Kromer, B., McCormac, G., van der Plicht, J., Spurk, M., 1998.

INTCAL98 radiocarbon age calibration, $24,000-0$ cal BP. Radiocarbon 40, 3, 1041-1083.

Tarasov, P.E., Harrison, S.P., Saarse, L., Pushenko, M.Ya., Andreev, A.A., Aleshinskaya, Z.V., Davydova, N.N., Dorofeyuk, N.I., Efremov, Yu.V., Khomutova, V.I., Sevastyanov, D.V., Tamosaitis, J., Uspenskaya, O.N., Yakushko, O.F., Tarasova, I.V., 1994. Lake status records from the former Soviet Union and Mongolia: Data base documentation. NOAA Paleoclimatology Publications Series Report 2, 274 pp.

Tarasov, P. E., Webb III, T., Andreev, A. A., Afanas'eva, N. B., Berezina, N.

A., Bezusko, L. G., Blyakharchuk, T. A., Bolikhovskaya, N. S., Cheddadi, R., Chernavskaya, M. M., Chernova, G. M., Dorofeyuk, N. I., Dirksen, V. G., Elina, G. A., Filimonova, L. V., Glebov, F. Z., Guiot, J., Gunova, V. S., Harrison, S. P., Jolly, D., Khomutova, V. I., Kvavadze, E. V., Osipova, I. M., Panova, N. K., Prentice, I. C., Saarse, L., Sevastyanov, D. V., Volkova, V. S., and Zernitskaya, V. P., 1998. Present-day and mid-Holocene biomes reconstructed from pollen and plant macrofossil data from the former Soviet Union and Mongolia. Journal of Biogeography 25, 1029-1053.

USDA, 2006. Caspian Sea heights variations. www.pecad.fas.usda.gov/cropexplorer/global reservoir/gr regional char 
t.cfm?regionid=metu\&region=\&reservoir name=Caspian. Visited 29 Decembre 2006.

van Geel, B., 2001. Non-pollen palynomorphs. In: Smol, J.P., Birks, H.J.B., Last, W.M. (Eds.), Tracking environmental change using lake sediments. Volume 3: Terrestrial, algal and silicaceous indicators. Kluwer, Dordrecht, pp. 99-119.

Wall, D., Dale, B., 1973. Paleosalinity relationships of dinoflagellates in the Late Quaternary of the Black Sea - a summary. Geoscience and Man 7, 95-102.

Wall, D., Dale, B., Harada, K., 1973. Descriptions of new fossil dinoflagellates from the Late Quaternary of the Black Sea. Micropaleontology 19, 1, 1831.

Wall, D., Dale, B., Lohmann, G.P., Smith, W.K., 1977. The environmental and climatic distribution of dinoflagellate cysts in the North and South Atlantic Oceans and adjacent seas. Marine Micropaleontology 2, 121 200.

Walter, H., 1974. Die Vegetation Osteuropas, Nord- und Zentralasiens. G. Fischer Verlag, Stuttgart.

Walter, H., Breckle, S.-W., 1989. Temperate and polar zonobiomes of northern Eurasia. Springer-Verlag.

Wick, L., Lemcke, G., Sturm, M., 2003. Evidence of Lateglacial and Holocene climatic change and human impact in eastern Anatolia: high-resolution pollen, charcoal, isotopic and geochemical records from the laminated sediments of Lake Van, Turkey. The Holocene 13, 5, 665-675.

Wilmshurst, J.M., McGlone, S.S., 2005. Corroded pollen and spores as indicators of changing lake sediment sources and catchment disturbance. Journal of Paleolimnology 34, 503-517.

Zenkevitch, L.A., 1963. Biology of the Seas of the USSR. George Allen and Unwin Ltd, London.

Zonneveld, K.A.F., Versteegh, G.J.M., de Lange, G.J., 2001.

Palaeoproductivity and post-depositional aerobic organic matter decay reflected by dinoflagellate cyst assemblages of the Eastern Mediterranean S1 sapropel. Marine Geology 172, 181-195. 


\section{Figure and table captions}

Fig. 1a: Location of the Caspian Sea in relation to neighbouring seas; fig. $1 \mathrm{~b}$ : Location map of the cores and the main inflow in the Caspian Sea.

Fig. 2: Long and short core lengths. Ages of core CP14 in calibrated radiocarbon years before present obtained by interpolation. The grey boxes represent phases of less brackish waters and river inflow. $\mathrm{Pl} / \mathrm{Ho}$ : Pleistocene/Holocene boundary.

Fig. 3: Carbonate values for the three pilot cores.

Fig. 4: ${ }^{137} \mathrm{Cs}\left(\mathrm{Bq} \cdot \mathrm{kg}^{-1}\right)$ (left) and ${ }^{210} \mathrm{Pbexc}\left(\mathrm{Bq} \cdot \mathrm{kg}^{-1}\right)$ (right) versus depth in $\mathrm{cm}$ in US02, south basin of the Caspian Sea.

Fig. 5: The concentration in pollen and spores, the concentration in dinocysts and the P:D ratios (concentrations) for the three cores. The three boxes represent phases of less brackish waters and river inflow.

Fig. 6: Pollen and spores percentages for core CP14, south basin. Diagrams are plotted using Psimpoll (Bennett, 2003) with 10x exaggeration curves and dots for values lower than $0.5 \%$.

Fig. 7: Pollen and spores percentages for core CP18, middle basin. Explanation of the diagram: as in Fig. 6.

Fig. 8: Pollen and spores percentages for core CP21, north of middle basin. Explanation of the diagram: as in Fig. 6.

Fig. 9: Percentages and concentration diagram for the dinoflagellates of core CP14, south basin. Diagrams are plotted using Psimpoll (Bennett, 2003) with $10 x$ exaggeration curves and dots for values lower than $0.5 \%$ or 50 grains per $\mathrm{ml}$.

Fig. 10: Percentages and concentration diagram for the dinoflagellates of core CP18, middle basin. Explanation of the diagram: as in Fig. 9.

Fig. 11: Percentages and concentration diagram for the dinoflagellates of core CP21, north of middle basin. Explanation of the diagram: as in Fig. 9.

Fig. 12: Percentages of years with monthly mean winds blowing from different directions using bins of $20^{\circ}$ for a grid point at $41^{\circ} \mathrm{N}, 51^{\circ} \mathrm{E}$. See appendix 2 for further explanation.

Table 1: Radiocarbon dates for cores CP14, 18 and 21. act. = activity, water corr. $=$ correction for water activity, detrit. = detrital fraction, corr. $=$ corrections, cal. $=$ calibrated, $\mathrm{msr}=$ mean sedimentation rate .

Table 2: Summary of pollen zones and their characteristics. [ ]= concentration. $\mathrm{Pz}=$ pollen zone.

Table 3: Summary of the dinocyst zonation and their characteristics. I. casp. = I. caspienense; L. mach. $=$ L. machaerophorum; S. cruc. $=S$. cruciformis.

Table 4: Ecological interpretation of all palynological indicators, zone by zone.

$\mathrm{Pz}=$ pollen and spores zones; $\mathrm{dz}=$ dinocyst zones. 


\section{Tables}

Table 1.

\begin{tabular}{|c|c|c|c|c|c|c|c|c|c|}
\hline Core & $\begin{array}{l}\text { depth } \\
\text { in } \mathrm{cm}\end{array}$ & act. & $\begin{array}{l}\text { error } \\
\pm \text { act }\end{array}$ & $\begin{array}{c}\text { meas. } \\
\text { age }\end{array}$ & $\begin{array}{l}\text { water } \\
\text { corr. }\end{array}$ & $\begin{array}{l}\text { detrit. } \\
\text { in } \%\end{array}$ & $\begin{array}{l}\text { both } \\
\text { corr. }\end{array}$ & $\begin{array}{l}\text { cal. } \\
\text { age }\end{array}$ & $\begin{array}{c}\text { mean } \\
\text { msr }\end{array}$ \\
\hline \multirow[t]{3}{*}{ CP14 } & 1 & 75.23 & 0.71 & 2286 & 692 & 8.6 & 1414 & 809 & 0.035 \\
\hline & 58.5 & 61.42 & 0.4 & 3915 & 2321 & 8.2 & 3008 & 2471 & 0.027 \\
\hline & 133.5 & 43.22 & 0.47 & 6738 & 5144 & 9.1 & 5910 & 5217 & \\
\hline \multirow[t]{2}{*}{ CP18 } & 1 & 48.11 & 0.76 & 5877 & & high & & & \\
\hline & 98.5 & 38.61 & 0.42 & 7644 & & high & & & \\
\hline \multirow[t]{2}{*}{ CP21 } & 13.5 & 48.08 & 0.73 & 5882 & & high & & & \\
\hline & 157 & 41.73 & 0.43 & 7020 & & high & & & \\
\hline
\end{tabular}


Table 2.

\begin{tabular}{|c|c|c|c|c|c|c|c|c|}
\hline $\begin{array}{l}\mathrm{CP} \\
14\end{array}$ & $\begin{array}{l}\text { Main } \\
\text { taxa }\end{array}$ & $\begin{array}{l}\text { Secondary } \\
\text { taxa }\end{array}$ & $\begin{array}{l}\text { CP } \\
18\end{array}$ & Main taxa & $\begin{array}{l}\text { Secondary } \\
\text { taxa }\end{array}$ & $\begin{array}{l}C P \\
21\end{array}$ & $\begin{array}{l}\text { Main } \\
\text { taxa }\end{array}$ & $\begin{array}{l}\text { Secondary } \\
\text { taxa }\end{array}$ \\
\hline Pz2c & $\begin{array}{l}\mathrm{A}-\mathrm{C}, \\
\text { diverse } \\
\mathrm{AP}\end{array}$ & High [ ] & Pz2 & Artemisia & $\begin{array}{l}\text { low AP } \\
\text { high [ ] }\end{array}$ & Pz3 & $\begin{array}{l}\text { A-C, } \\
\text { Artemisia }\end{array}$ & $\begin{array}{l}\text { low AP, } \\
\text { high [] }\end{array}$ \\
\hline Pz2b & $\begin{array}{l}A-C, \\
\text { Pinus }\end{array}$ & $\begin{array}{l}\text { Spores, } \\
\text { drop of [ ] }\end{array}$ & & & & Pz2 & $A-C$ & $\begin{array}{l}\text { Ephedra, } \\
\text { increasing [] }\end{array}$ \\
\hline Pz2a & $\begin{array}{l}A-C, \\
\text { low AP }\end{array}$ & Increasing [ ] & & & & Pz1b & Pinus & $\begin{array}{l}\text { spores, } \\
\text { reworked, } \\
\text { Salvinia, } \\
\text { v. low [ ] }\end{array}$ \\
\hline Pz1 & $\begin{array}{l}\text { A-C, } \\
\text { Pinus }\end{array}$ & $\begin{array}{l}\text { Compositae, } \\
\text { Spores, } \\
\text { reworked, } \\
\text { Salvinia, } \\
\text { low [ ] }\end{array}$ & Pz1 & $\begin{array}{l}\mathrm{A}-\mathrm{C}, \\
\text { Artemisia }\end{array}$ & $\begin{array}{l}\text { low AP, } \\
\text { Gramineae, } \\
\text { Cerealia-t. }\end{array}$ & Pz1a & $A-C$ & $\begin{array}{l}\text { Pinus, } \\
\text { reworked, } \\
\text { low [ ] }\end{array}$ \\
\hline
\end{tabular}


Table 3.

\begin{tabular}{|l|l|l|l|l|l|l|l|}
\hline CP14 & Main taxa & $\begin{array}{l}\text { Secondary } \\
\text { taxa }\end{array}$ & CP18 & Main taxa & CP21 & $\begin{array}{l}\text { Main } \\
\text { taxa }\end{array}$ & $\begin{array}{l}\text { Secondary } \\
\text { taxa }\end{array}$ \\
\hline Dz3 & I. casp. & $\begin{array}{l}\text { L. mach. } \\
\text { C. rugosum } \\
\text { S. cruc. }\end{array}$ & Dz3 & I. casp. & Dz3 & I. casp. & $\begin{array}{l}\text { L. mach. } \\
\text { C. rugosum }\end{array}$ \\
\hline Dz2 & $\begin{array}{l}\text { I. casp. } \\
\text { Dz1 }\end{array}$ & $\begin{array}{l}\text { P. psilata } \\
\text { S. cruc. }\end{array}$ & Dz2 & $\begin{array}{l}\text { I. casp. } \\
\text { L. mach. }\end{array}$ & Dz2 & I. casp. & S. cruc. \\
\hline
\end{tabular}


Table 4.

\begin{tabular}{|l|l|l|l|l|l|}
\hline CP14 & CP18 & CP21 \\
\hline pz & dz & pz & dz & pz & dz \\
\hline $\begin{array}{l}\text { 2c semi- } \\
\text { desert }\end{array}$ & 3 brackish & 2 steppe & 3 brackish & 3 steppe & 3 brackish \\
\hline 2b river input & $\begin{array}{l}\text { 3 lower } \\
\text { salinity }\end{array}$ & $\begin{array}{l}\text { 2 steppe } \\
\text { (more } \\
\text { productive) }\end{array}$ & $\begin{array}{l}2 \text { more } \\
\text { brackish }\end{array}$ & 2 desert & 3 brackish \\
\cline { 5 - 6 } 2a desert & 2 brackish & 1b river input & 2 low salinity \\
\hline 1 river input & $\begin{array}{l}\text { 1 low } \\
\text { salinity }\end{array}$ & 1 semi-desert & 1 brackish & 1a desert & 1 low salinity \\
\hline
\end{tabular}




\section{Appendices}

\section{Appendix 1}

Core numbering and location. All locations and water depths are approximate owing to poor weather conditions and navigation tools performances.

$\begin{array}{llll}\text { On board no } & \begin{array}{l}\text { Museum no } \\ \text { Core length }(\mathrm{cm})\end{array} & \text { here } & \begin{array}{l}\text { Latitude }(\mathrm{N}) \text {, longitude (E), } \\ \text { water depth }(\mathrm{m})\end{array} \\ \text { SR9402GS05 } & \begin{array}{l}\text { SR01GS9405 } \\ 957\end{array} & \text { GS05 } & 38^{\circ} 46^{\prime}, 51^{\circ} 32^{\prime}, 518 \\ \text { SR9406US14 } & \begin{array}{l}\text { SR01US9402 } \\ \text { 50 }\end{array} & \text { US02 } & 3^{\circ} 16^{\prime}, 51^{\circ} 28^{\prime}, 315 \\ \text { SR9406CP16 } & \begin{array}{l}\text { SR01GS9414CP } \\ \text { 140 }\end{array} & \text { CP14 } & 3^{\circ} 16^{\prime}, 51^{\circ} 28^{\prime}, 330 \\ \text { SR9409CP20 } & \begin{array}{l}\text { SR01GS9418CP } \\ \text { 182 }\end{array} & \text { CP18 } & 41^{\circ} 33^{\prime}, 51^{\circ} 06^{\prime}, 480 \\ \text { SR9409GS20 } & \begin{array}{l}\text { SR01GS9418 } \\ \text { 995 }\end{array} & \text { GS18 } & 41^{\circ} 33^{\prime}, 51^{\circ} 06^{\prime}, 479 \\ \text { SR9411CP23 } & \begin{array}{l}\text { SR01GS9421CP } \\ 170\end{array} & \text { CP21 } & 42^{\circ} 51^{\prime}, 49^{\circ} 51^{\prime}, 460\end{array}$




\section{Appendix 2}

The daily radiosond observations for January and July and monthly means of the wind analysis since 1958 are available in the archive of the reanalysis project at ECMWF (Simmons \& Gibson, 2000). The wind data of the $850 \mathrm{hPa}$ level (about $1200 \mathrm{~m}$ high) are probably most suitable for this investigation as the pollen had to be carried for long distances and therefore at a level higher than the surface. This is also a standard level for meteorological observations. The monthly means of the wind analysis data are averages of the zonal and meridional components and could be misleading in extreme conditions, e.g. if in the unlikely event the wind is blowing half the month from the west and the other half from the east this average would give zero wind. For January and July, this possibility has been checked by using the daily or 6 hourly radiosond observations. However, for the purpose here, using such averages might be the most suitable approach because the pollen will only be able to reach the coring sites if the wind blows from the same direction over a longer period. Figure 12 shows the probability of winds blowing out different directions in bins of $20^{\circ}$. The definition for wind direction as commonly used in meteorology is used here: wind from the north has a direction $0^{\circ}$ or $360^{\circ}$ that from the east has a direction $90^{\circ}$, from the south $180^{\circ}$ and from the west $270^{\circ}$. To obtain these values from the monthly means of the zonal and meridional wind components, for each month (1958-2002) the direction and the speed are recalculated. Only months in which the wind speed exceeds $0.6 \mathrm{~m} / \mathrm{s}$ are used to do the binning into $20^{\circ}$ samples. For normalization the occurrence in each bin is divided by the number of years used for the statistic.

From the end of the winter to the beginning of the summer, the winds progressively shift from the west (February) to the SW (April). Then after May (which is a transition month) from SW to SE, the winds of June and July are mainly from the east and north-east.

Simmons, A. J., Gibson, J. K., 2000. The ERA-40 Project Plan. ERA-40 Project Report Series, 1, 63 pp, ECMWF, Shinfield Park, Reading, UK. 